\title{
REDD+: Combating Climate Change with Forest Science
}

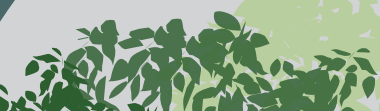
3. ni. a w wa S 10

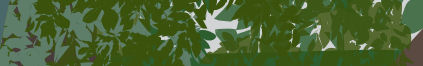

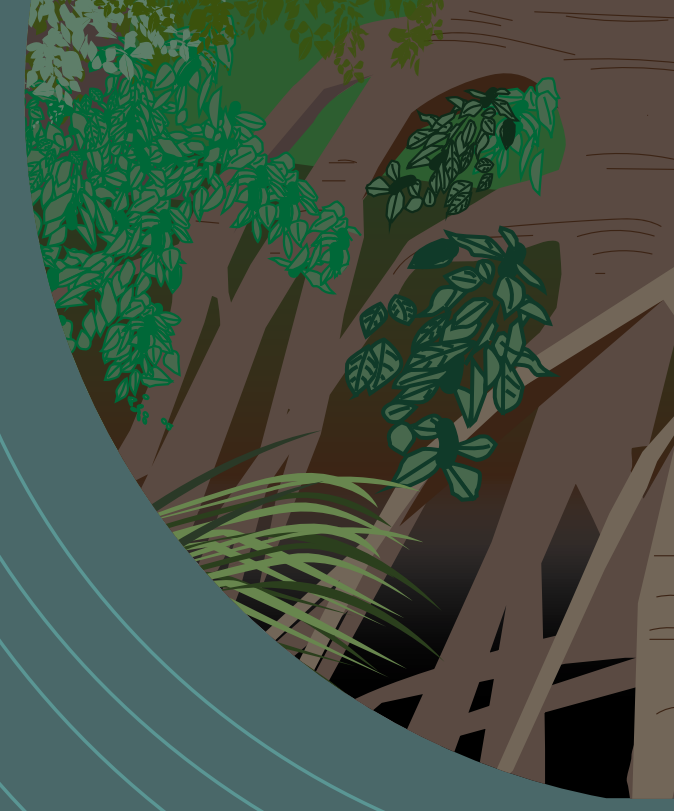

Ten years of

forests, trees and agroforestry research in partnership for sustainable development 


\section{About the FTA Highlights series}

This publication is part of a series that highlights the main findings, results and achievements of the CGIAR Research Program on Forests, Trees and Agroforestry (FTA), from 2011 to 2021 (see full list of chapters on the last page).

FTA, the world's largest research for development partnership on forests, trees and agroforestry, started in 2011. FTA gathers partners that work across a range of projects and initiatives, organized around a set of operational priorities. Such research was funded by multiple sources: GGIAR funders through program-level funding, and funders of bilateral projects attached to the programme, undertaken by one or several of its partners. Overall this represented an effort of about 850 million USD over a decade.

The ambition of this series is, on each topic, to show the actual contributions of FTA to research and development challenges and solutions over a decade. It features the work undertaken as part of the FTA program, by the strategic partners of FTA (CIFOR-ICRAF, The Alliance of Bioversity and CIAT, CATIE, CIRAD, Tropenbos and INBAR) and/or with other international and national partners. Such work is presented indifferently in the text as work "from FTA" and/ or from the particular partner/organization that led it. Most of the references cited are from the FTA program.

This series was elaborated under the leadership of the FTA Director, overall guidance of an Editorial Committee constituted by the Management Team of FTA, support from the FTA Senior Technical Advisor, and oversight of the FTA Independent Steering Committee whose independent members acted as peer-reviewers of all the volumes in the series.

FTA HIGHLIGHTS OF A DECADE 2011-2021

REDD+: Combating Glimate Change with Forest Science

(C) 2021 The GGIAR Research Program on Forests, Trees and Agroforestry (FTA)

Content in this publication is licensed under a Creative Commons Attribution 4.0

International (CC BY 4.0), http://creativecommons.org/licenses/by/4.0/

DOI: $10.17528 /$ cifor/008221

Martius C and Duchelle AE. 2021. REDD+: Combating Climate Change with Forest Science. FTA Highlights of a Decade 2011-2021 series. Highlight No. 11. Bogor, Indonesia: The CGIAR Research Program on Forests, Trees and Agroforestry (FTA).

CGIAR Research Program on Forests, Trees and Agroforestry

CIFOR Headquarters

Jalan CIFOR

Situ Gede, Sindang Barang

Bogor Barat 16115 Indonesia

$\mathrm{T}+62-251-8622-622$

E cgiarforestsandtrees@cgiar.org

foreststreesagroforestry.org

We would like to thank all funding partners who supported this research through their contributions to the CGIAR Fund. For a full list of the 'CGIAR Fund' funding partners please see: http:/ / www.cgiar.org/ ourfunders.

Any views expressed in this publication are those of the authors. They do not necessarily represent the views of The CGIAR Research Program on Forests, Trees and Agroforestry (FTA), the editors, the authors' institutions, the financial sponsors or the reviewers.
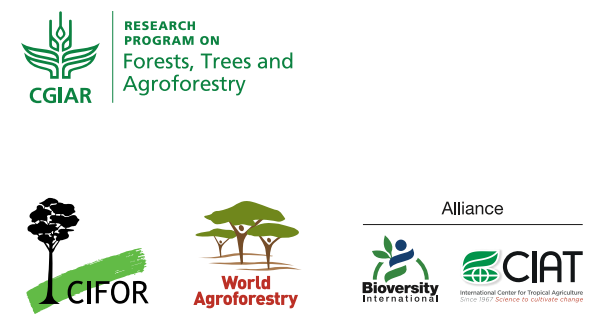
FTA HIGHLIGHTS OF A DECADE

$2011-2021$

\section{REDD+: Combating Glimate Change with Forest Science}

Authors: Christopher Martius and Amy E. Duchelle 


\section{Editorial and publication team}

\section{Editorial Committee of the Highlights Series}

Vincent Gitz (Chairperson of the Editorial Committee), Michael Allen Brady, René Boot, Marlène Elias, Ramni H. Jamnadass, Christopher Kettle, Yanxia Li, Christopher Martius, Alexandre Meybeck, Peter A. Minang, Fergus Sinclair, Plinio Sist and Eduardo Somarriba.

\section{Independent Steering Committee of FTA}

Anne-Marie Izac (Chairperson of the ISC), René Boot, Susan Braatz, Linda Collette, Vincent Gitz, Florencia Montagnini, Richard Stanislaus Muyungi, Robert Nasi and Stephan Weise.

\section{FTA Director}

Vincent Gitz

\section{FTA Highlights Support Team}

Technical and scientific editing: Alexandre Meybeck, FTA senior technical advisor Coordination of publication process, editing and layout: Fabio Ricci, FTA communications coordinator

Coordination of the peer-review process: Monika Kiczkajlo, FTA program manager Language editing and referencing: Patricia Halladay, consultant

Layout and design: Dharmi Bradley, consultant

\section{Acknowledgements}

The authors are greatly indebted to Deanna Ramsay for compiling information, drafting a first version of this text, and supporting us further all the way to a readable paper. This research is part of CIFOR's Global Comparative Study on REDD+ (www.cifor.org/gcs). We would also like to acknowledge the GCS REDD+ module leaders for the third phase of the program, namely Pham Thu Thuy, Veronique De Sy, Anne Larson and Jeremy Van Loon, along with the dozens of CIFOR colleagues and partners who have made meaningful contributions to GCS REDD+ over the years. The funding partners that have supported this research include the Norwegian Agency for Development Cooperation (Norad) [Grant no. QZA-16/0110 No. 1500551], the International Climate Initiative (IKI) of the German Federal Ministry for the Environment, Nature Conservation, Building and Nuclear Safety (BMUB) [Grant no. KI II 7 - 42206-6/75], and the CGIAR Research Program on Forests, Trees and Agroforestry (FTA), with financial support from the CGIAR Fund Donors.

The authors thank Anne-Marie Izac and Richard S. Muyungi for their constructive review and feedback on an earlier version of the manuscript. 


\section{Table of contents}

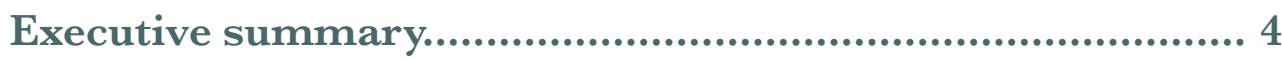

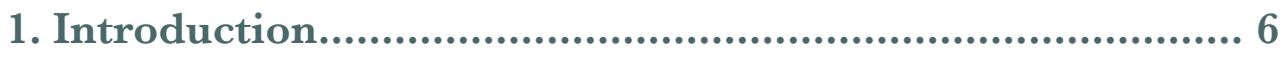

2. Laying the foundations for impact...................................... 9

3. Results in countries............................................................. 13

4. Global impacts......................................................................... 21

5. Learning on how to achieve successes at scale.................... 24

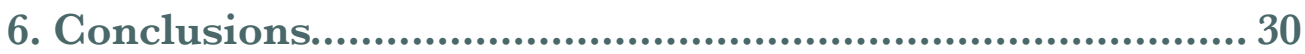

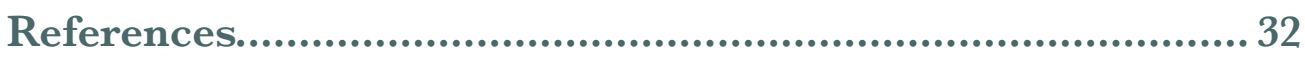

Annex 1: Program evaluation reports and links...................... 35

\section{List of acronyms}

BRG Badan Restorasi Gambut (Peatland Restoration Agency)

FORDA/ Forestry and Environmental Research, Development and Innovation

FOERDIA Agency of the Ministry of Environment and Forestry

FREL Forest Reference Emissions Levels

GCF Green Climate Fund

GCS REDD+ Global Comparative Study on REDD+

GHG Greenhouse gas

INCAS Indonesian National Carbon Accounting System

ITPC International Tropical Peatlands Center

LORTA Learning-Oriented Real-Time Impact Assessment

MRV Measurement, reporting and verification

ODI Overseas Development Institute

PFES Payment for Forest Environmental Services

REDD+ Reducing emissions from deforestation and forest degradation, and the role of conservation, sustainable management of forests,

SERNANP and enhancement of forest carbon stocks in developing countries

SWAMP Sustainable Wetlands Adaptation and Mitigation Program 


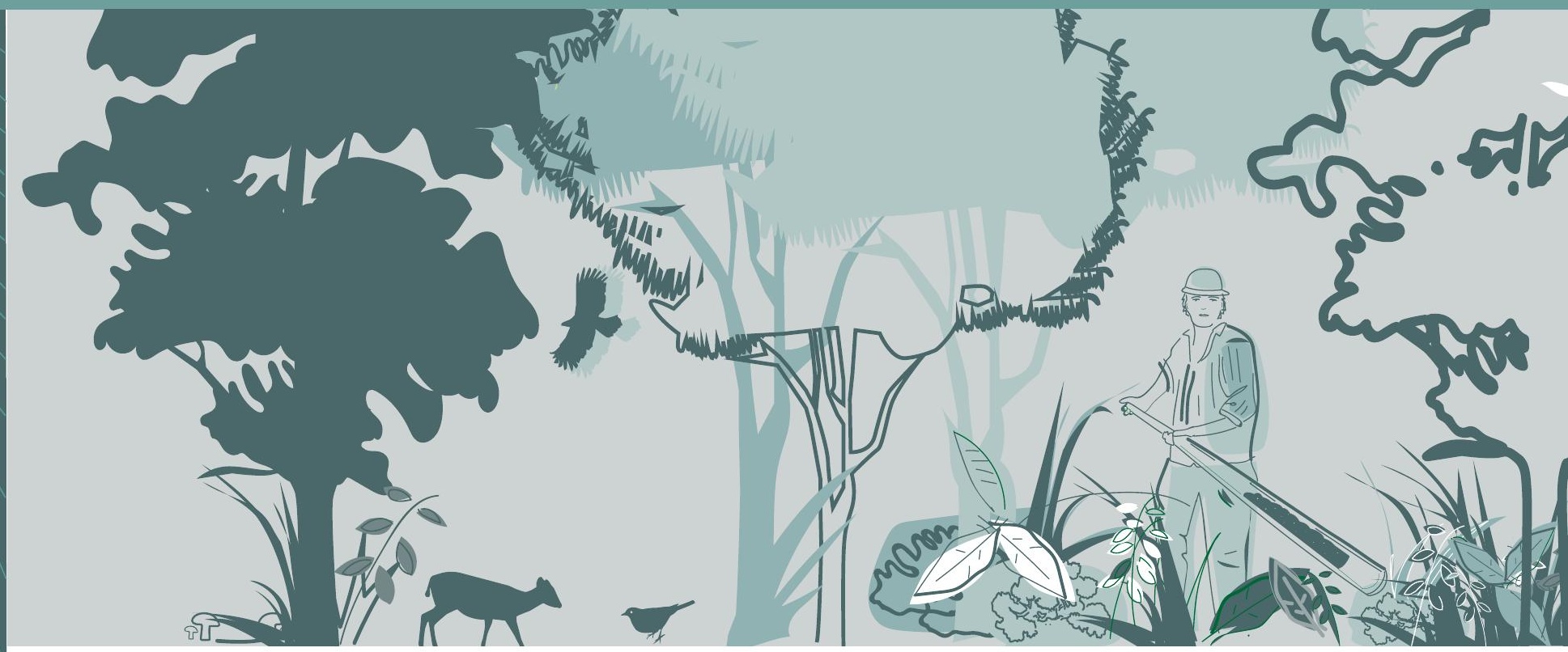

\section{Executive summary}

The climate change battle has many fronts; protecting the world's remaining forests is a major one. Land-use change, including deforestation, contributes $10-12 \%$ of global emissions (IPCC 2019), and the REDD+ framework (reducing emissions from deforestation and forest degradation) has been seen as a way to promote both climate and sustainable development benefits. Now enshrined in the Paris Agreement, the central offer of REDD+ consists of results-based payments to forest-rich countries for protecting forests and avoiding carbon emissions. The challenges associated with this approach are large, and a diversity of actors is needed to make it a success, including researchers. Could science contribute to make REDD+ more efficient, more effective and more equitable? Scientists with CIFOR's Global Comparative Study on REDD+ (GCS REDD+) have been analyzing REDD+ for the past 12 years. GCS REDD+ is the largest global research program of its kind and a major component of the CGIAR Research Program on Forests, Trees and Agroforestry (FTA). With dozens of national and subnational REDD+ initiatives and several hundred local projects underway, GCS REDD+ has looked at the range of approaches, analyzed conditions - from policy to land rights to forest monitoring capacity - and produced a bedrock of evidence and analysis across 22 countries. This ensures that policymakers and practitioner communities have the evidence they need to design and implement REDD+ with effective, cost-efficient and equitable outcomes.

This long-term work has resulted in contributions to global climate policy and learnings about the drivers of deforestation and the domestic conditions needed for successful forest protection, as well as a host of guidance for 


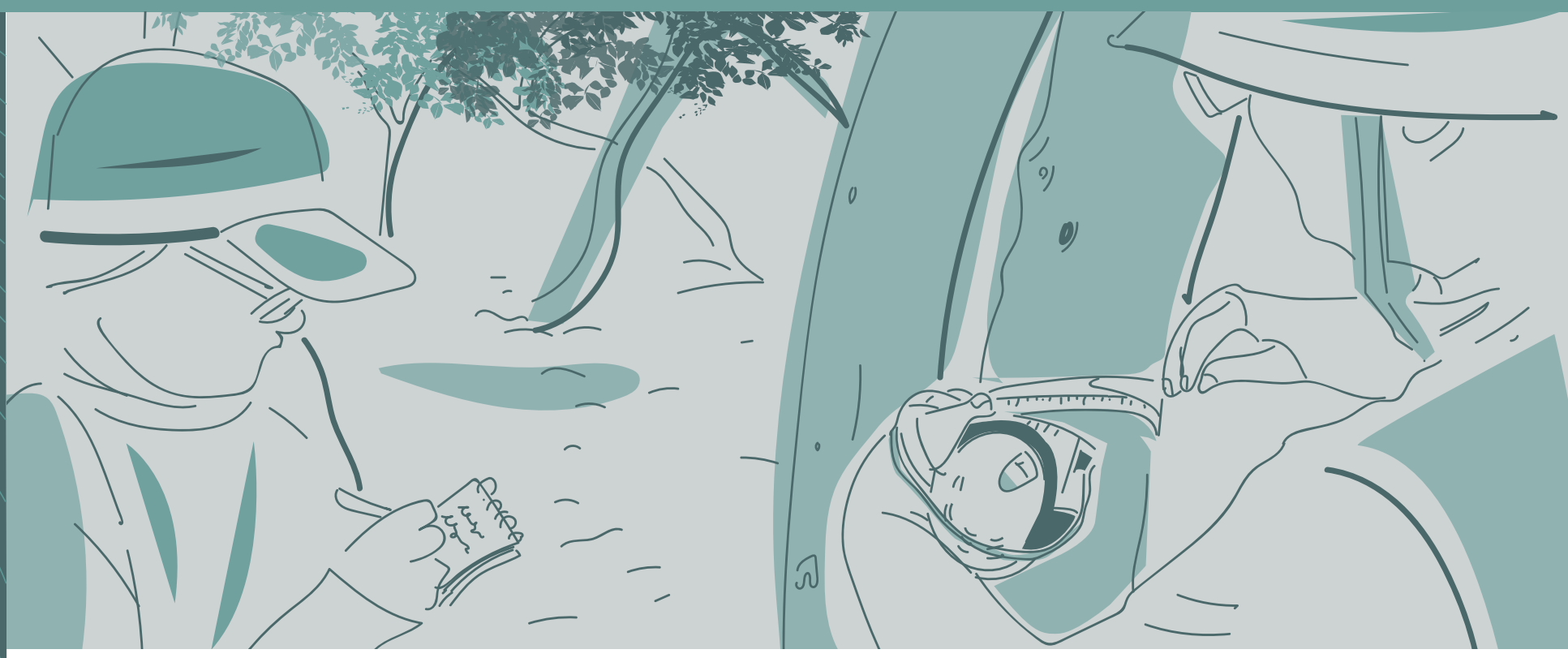

\section{Introduction}

It is clear that the climate battle will need to be fought by reducing the use of fossil fuels, requiring massive efforts across sectors. But, second to fuels, the land sector is vital to maintaining and rebuilding carbon sinks to achieve so-called "negative emissions"". To keep global warming below $1.5^{\circ} \mathrm{C}$, the world's forests must be protected, restored and sustainably managed (Griscom et al. 2017, 2020; Roe et al. 2019; IPCC 2019). With this knowledge, the strategy to reduce emissions from deforestation and forest degradation, known as REDD $+{ }^{3}$ has been at the top of the global climate agenda since 2007.

Now enshrined in the Paris Agreement, REDD+ aims to realize both climate and development benefits from forests. At its core is the offer of payments to countries for protecting forests and avoiding carbon emissions, through connecting international support to local and national action to mitigate climate change. This aim is ambitious, and implementation has been challenging. The ways people use land, the ways national policies and government priorities affect forests, determining carbon emissions and setting reference levels, and the establishment of social and environmental safeguards all intersect in achieving REDD+ goals.

Since 2007, more than 50 countries have initiated REDD+ strategies and many subnational governments have made formal commitments to reducing

\footnotetext{
${ }^{2}$ Negative emissions $=$ taking greenhouse gases from the atmosphere, e.g. through a carbon sink in vegetation. This paper does not address untested technological negative emission ideas such as bioenergy with carbon capture and storage (BECCS).

${ }^{3}$ REDD + stands for "reducing emissions from deforestation and forest degradation, and the role of conservation, sustainable management of forests, and enhancement of forest carbon stocks in developing countries"
} 
deforestation. As of December 2020, there were 377 active REDD+ projects across the tropics (Duchelle et al. 2019; Atmadja et al. in press).

The Global Comparative Study on REDD+ (GCS REDD+) started soon after REDD+ emerged, and is the largest global research programme on this subject. ${ }^{4}$ Scientists have been collecting data, conducting analysis and sharing experiences to determine what has worked and what hasn't with REDD+ across 22 countries (see Figure 1). They ask: What works to reduce deforestation? Where have the roadblocks been, and how can they be overcome? Does REDD+ have unintended negative consequences? What opportunities have emerged through this global mechanism that were not conceived of when it began?

GCS REDD+ research has been answering these questions so that policymakers and practitioner communities have access to the information they need to support the design and implementation of REDD+, and ultimately to achieve climate goals. This work also ensures that there is robust evidence to help REDD+ achieve effective, cost-efficient and equitable outcomes in policy design and implementation.

There are powerful interests (such as unsustainable timber extraction, conversion to agricultural land, mining, or land speculation) in maintaining the status quo of unsustainable deforestation and forest degradation. Recognizing this, GCS REDD+ research has looked at how to bring more people to the table, address underlying power relations and allow more, and new, voices to be heard.

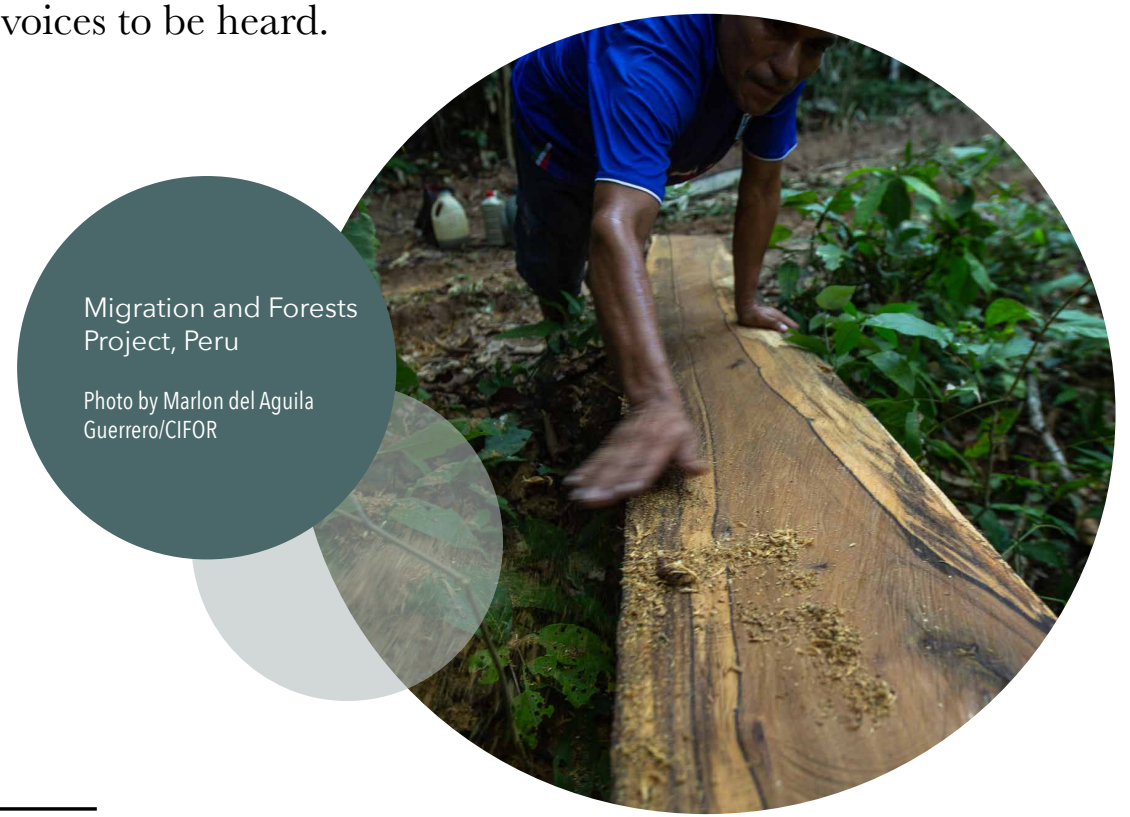

\footnotetext{
${ }^{4}$ This research is part of CIFOR's Global Comparative Study on REDD+ (www.cifor.org/gcs). See the Acknowledgements for the funding partners that have supported this research.
} 


\section{COUNTRIES WHERE GCS REDD+ HAS WORKED OR IS WORKING}

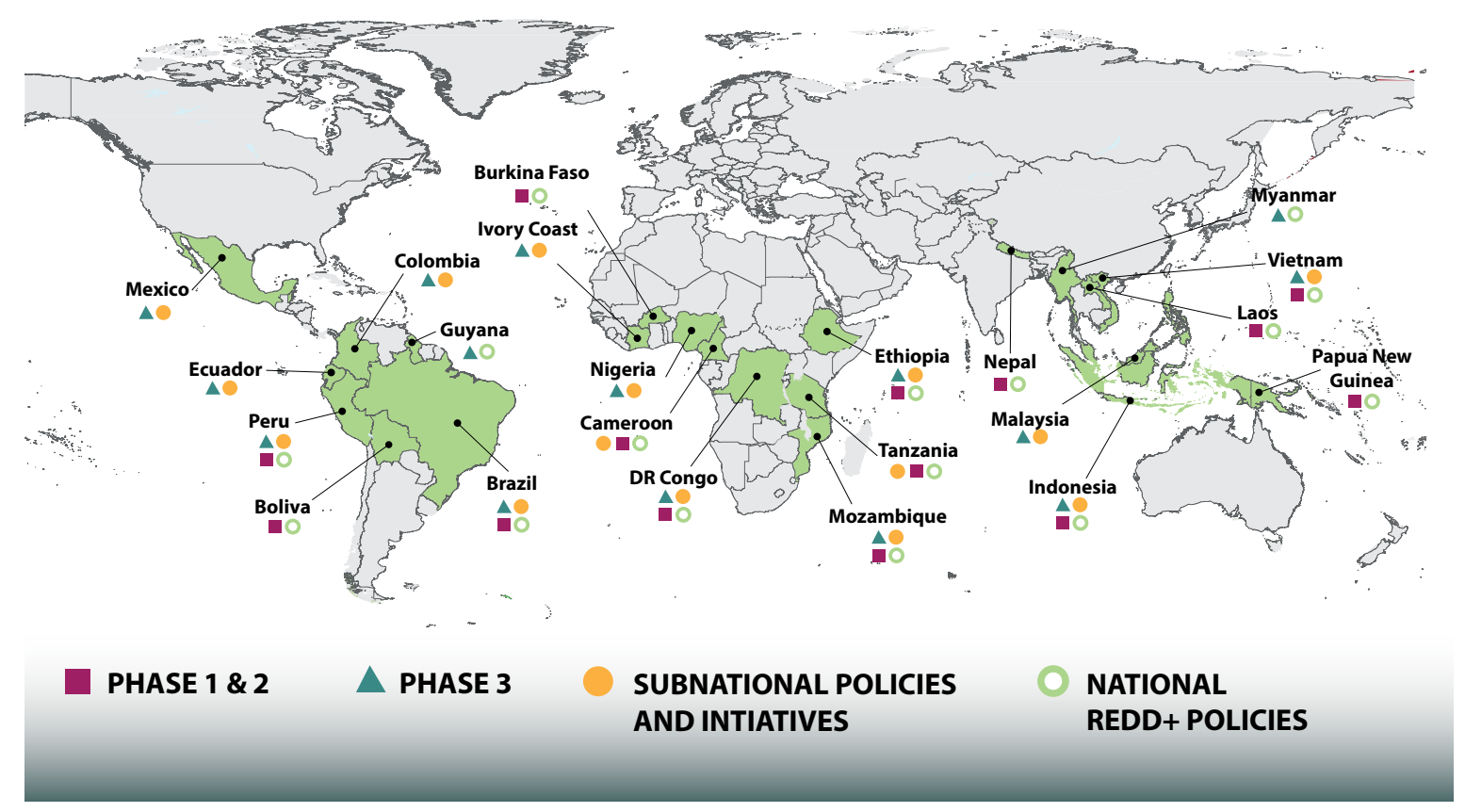

Figure 1. Countries where GCS REDD+ has worked or is working. The first phase of CIFOR's REDD+ program focused on overall policy design issues and building research-based knowledge; the second phase, on analysing policy processes and the actions of early starters in developing REDD+ policies; and the third phase, on the assessment of policy design and impacts of REDD+ policies and measures.

Since 2009, the GCS REDD+ program has produced extensive peerreviewed knowledge about REDD+ garnered from participatory surveys, field work to determine emissions levels, policy analysis and more. The knowledge generated was expected to help countries make more informed decisions along their REDD+ journeys. The 1,057 scientific publications, 207 briefs and 464 blogs, many translated into Bahasa Indonesia, French, Portuguese, Spanish and Vietnamese, reflect the GCS REDD+ goal of making its scientific knowledge available to the widest and most diverse audience possible.

But the program is doing more than just research, as the next sections show. 


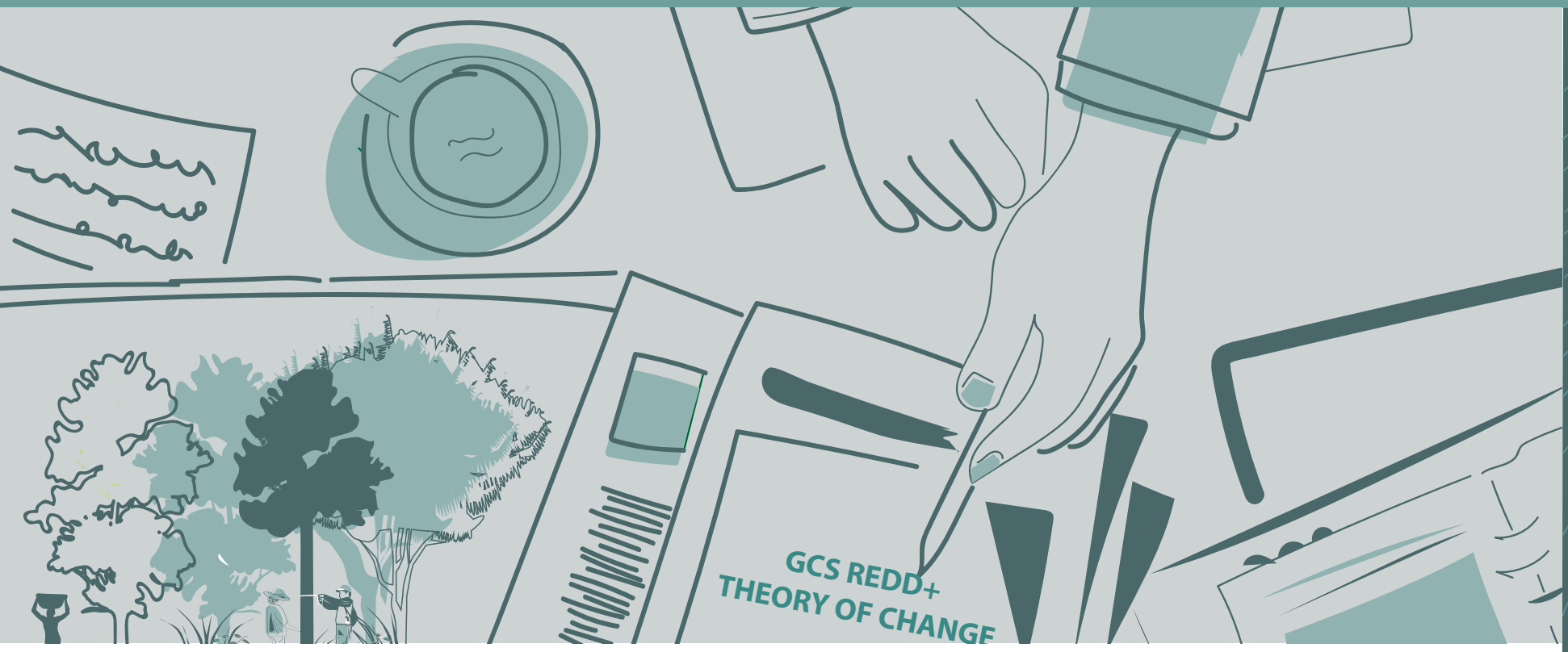

\section{Laying the foundations for impact}

The theory of change for GCS REDD+ provides direction for the program's work and the end goal to contribute to global efforts to reduce deforestation and forest degradation, promote sustainable development, and conserve biodiversity. With that goal front and centre, the theory of change outlines how GCS REDD+ activities are expected to contribute to those changes.

Effecting transformation at the various levels of policy and practice at which the GCS REDD+ program operates is a complex task. The theory of change therefore serves multiple purposes. It is a necessary planning tool. It is a framework for monitoring and evaluation. It is an analytical device. And it has also evolved over the years based on lessons learned and on feedback received from three program evaluations (Young and Bird 2015; Ducenne et al. 2019; Efeca 2021).

The theory of change details the main actors involved (from individuals to organizations to communities); identifies their actions as a sequence of steps or stages with short- and long-term outcomes; and explains who needs to do what differently to achieve the change. It also describes the causal assumptions about, theoretical explanations for and mechanisms by which each step is realized. One important assumption is that evidence-based scientific knowledge shared with policymakers and practitioners will be used by them to inform their decision-making. 
There is added complexity, since project activities are directly linked to the REDD + framework itself. As originally conceived, REDD + was to provide pathways for using conditional incentives to reduce emissions. But GCS REDD+ research has found that, in practice, REDD+ has evolved into a diversity of measures, with the core element of conditionality rarely applied (Sunderlin et al. 2015; Angelsen et al. 2018b). REDD+ implementation has been additionally complicated because of differing finance modalities (e.g. public versus market-based) and scales of implementation (e.g. projectlevel REDD+ versus national and subnational REDD+ programmes). Also, actors in the REDD+ sphere can fail to distinguish between REDD+ as the outcome of reduced emissions and the (UNFCGG) framework to achieve them (Angelsen et al. 2017; Martius et al. 2018).

It is amid this state of affairs that the program's theory of change has emerged and evolved. The theory of change reflects the knowledge that GCS REDD+ has developed during 12 years of research and engagement on how to effectively influence REDD+ policy and practice. This experience has emphasized how important it is that all stakeholders develop ownership of the knowledge produced and the agenda for its use. One evaluation of GCS REDD+ (Young and Bird 2015) found that its combination of co-producing research, extensive engagement of knowledge users across the research cycle, and targeted communications with key decision makers is effective in achieving ownership and use of information in REDD+ decision-making.

This is what the GCS REDD+ program is doing.

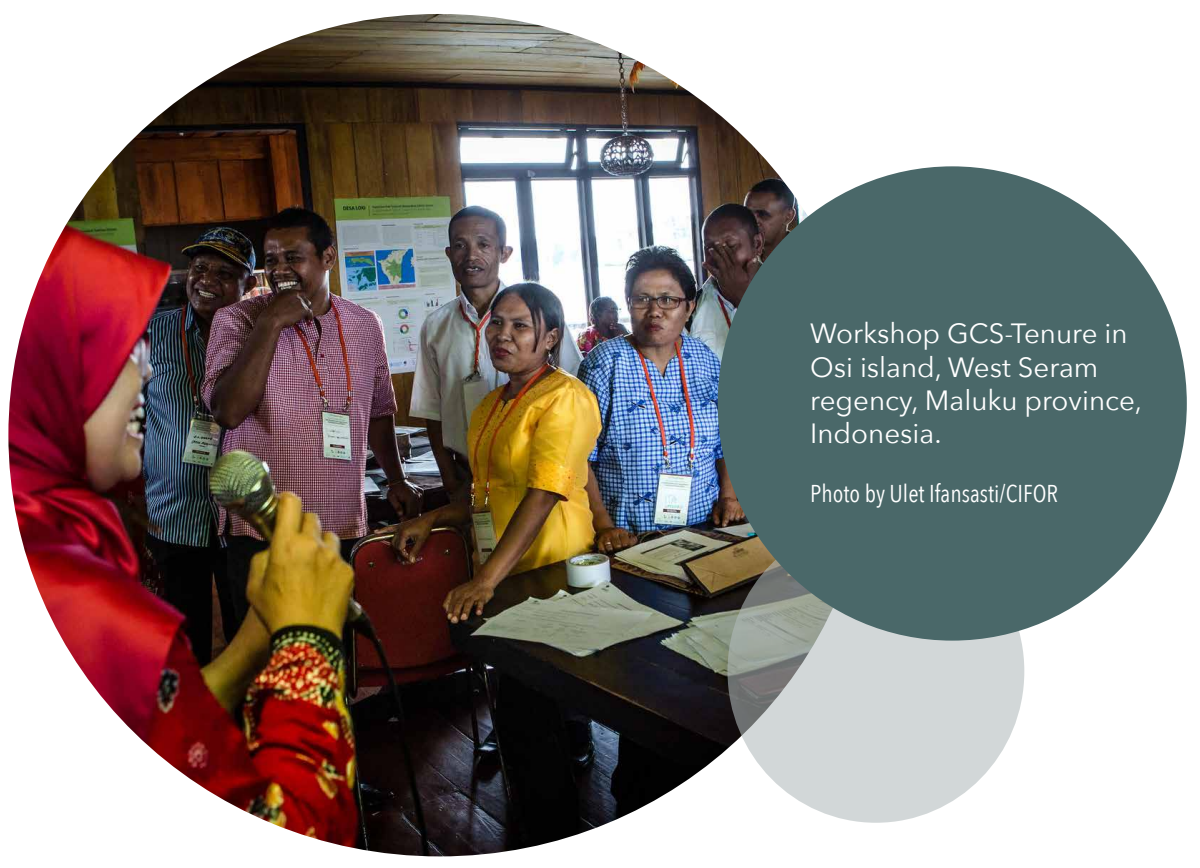


The theory of change is structured in five stages (see Figure 2). The first four are within the program's sphere of influence. Achieving the desired outcomes in these stages would mean that GCS REDD+ activities are affecting the REDD+-related decisions of key decision makers and practitioners. Throughout the years of REDD+ programme implementation, it is anticipated that there will be a transition from joint production of scientific evidence and learning to a point when policymakers and practitioners use that knowledge in their own decision-making. When this happens, the programme is achieving results; i.e. it is generating impact.

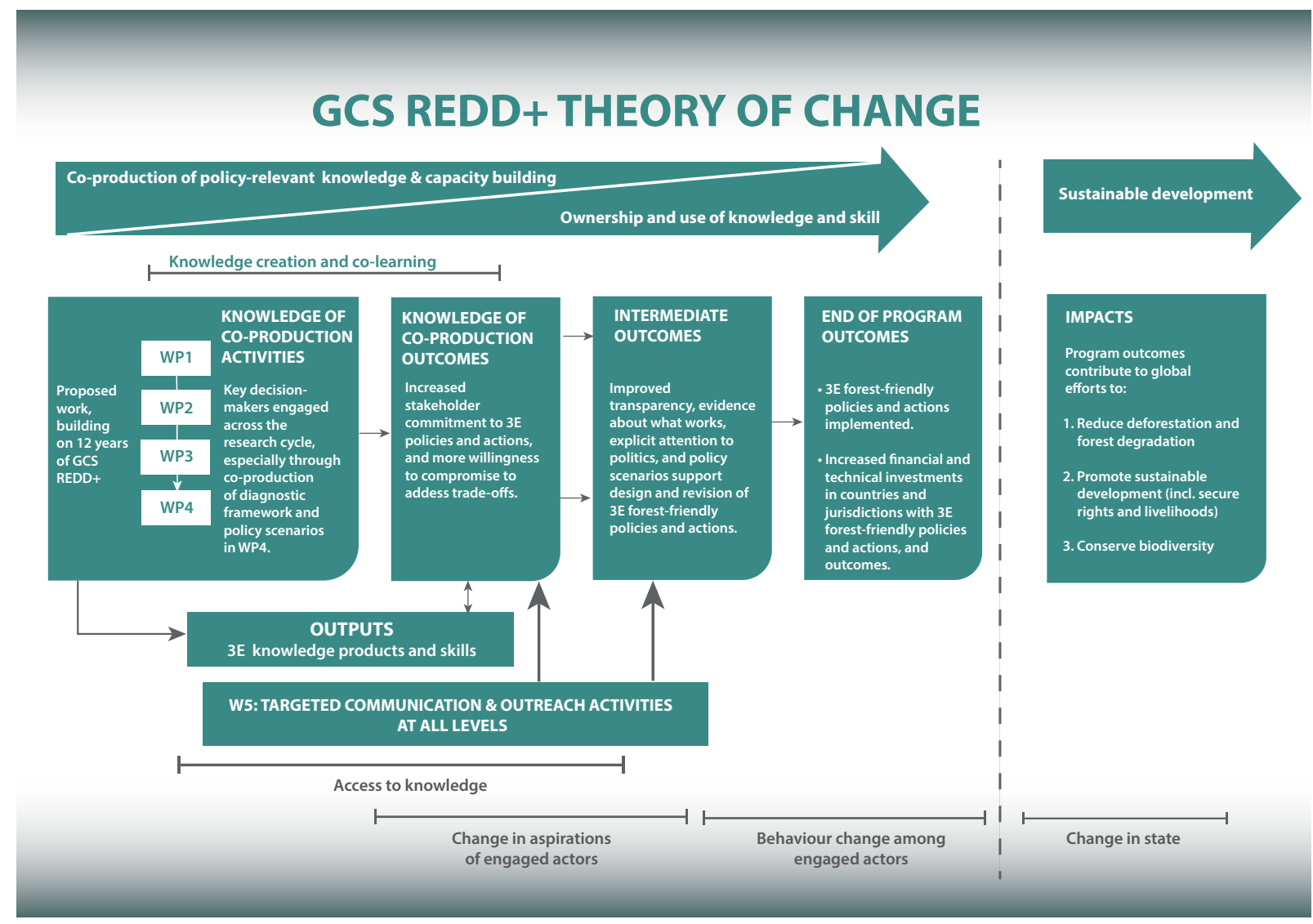

Figure 2. GCS REDD+ theory of change. WP: work package. $3 \mathrm{E}=$ efficient, effective and equitable

In each of the 22 study countries (see Figure 1), the program works collaboratively with key actors (such as policymakers, civil society organizations, Indigenous Peoples and the private sector) in a number of research modules or work packages: each module focuses on a priority area for sustainable REDD+ and private-sector initiatives appropriate to each country. As a result of this close engagement, people learn skills, internalize values and develop understanding, all of which influence how decisions are made in their respective areas of responsibility. 
The cumulative result of this knowledge co-production, communication and engagement are changes in what implementers and supporters aspire to achieve. This is reflected in how supporting organizations promote, motivate and enable implementation of REDD+ initiatives, and the extent to which people have the will, knowledge and support to pursue implementation. Implementers will have in hand relevant information, analysis and tools to create enabling conditions, design and implement initiatives, and assess the carbon and non-carbon performance of REDD+ initiatives.

By contributing to shifting behaviour away from business as usual towards the use of knowledge and evidence that results in effective, efficient and equitable outcomes throughout the lifecycle of REDD+ and private-sector initiatives, the GCS REDD+ program expects to have a long-term impact on the ability of target countries to protect and restore their forests.

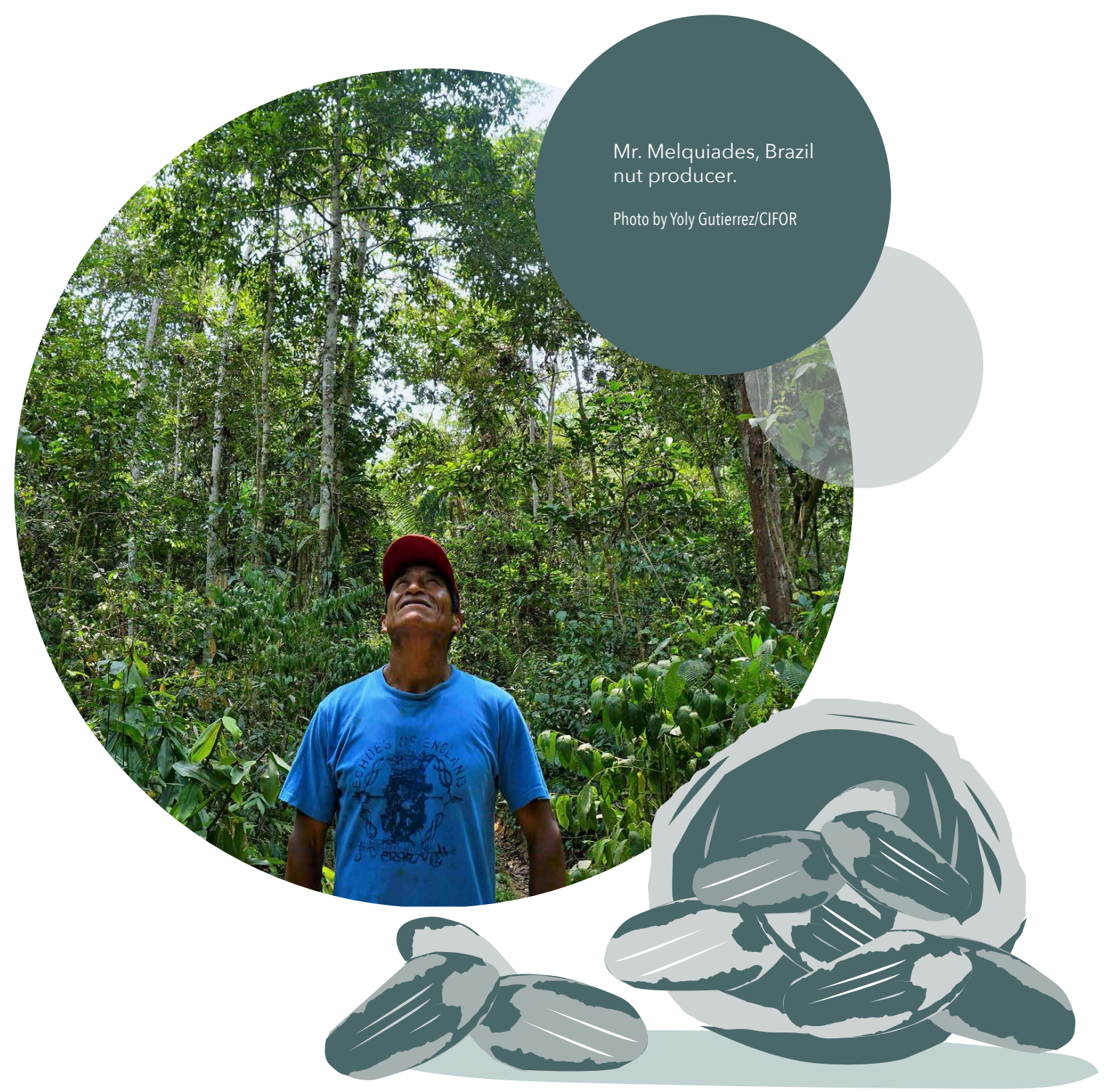




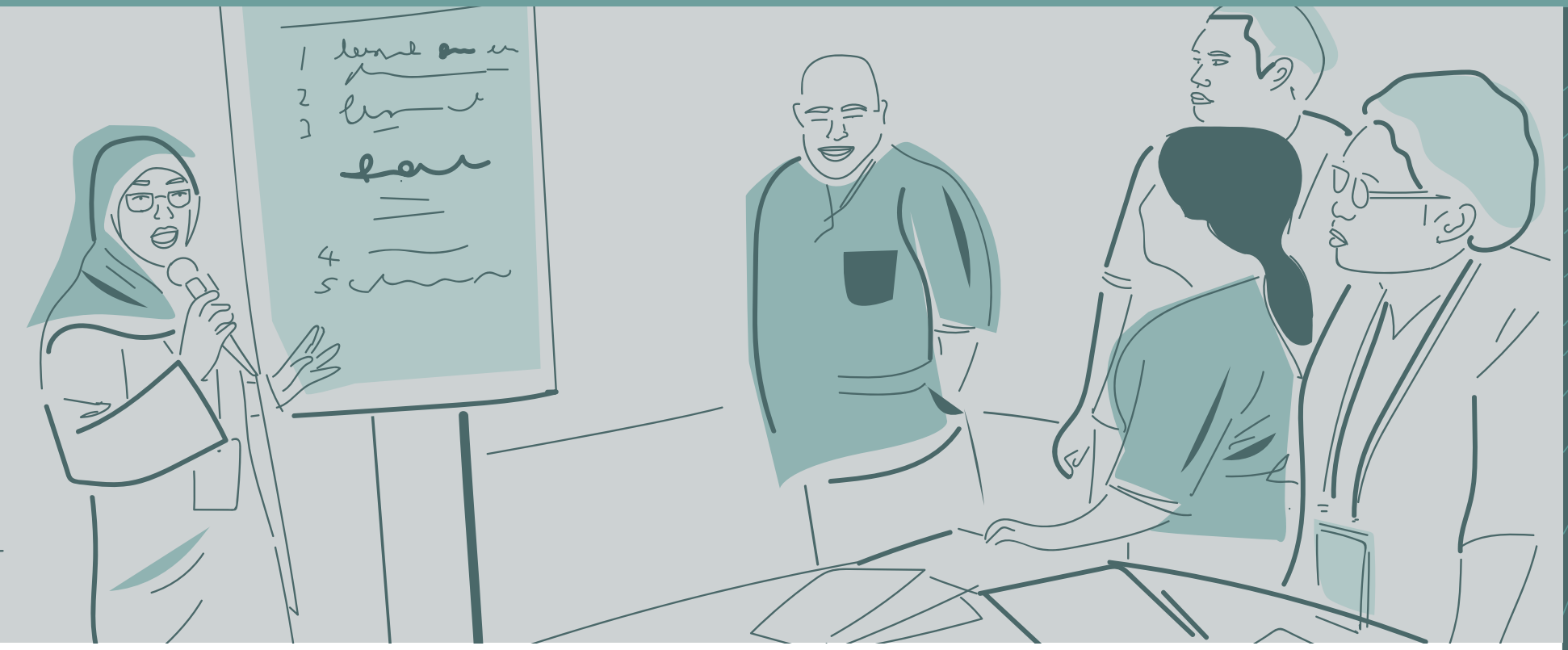

\section{Results in countries}

Strong engagement with local partners is essential, and the program has seen results at the national and jurisdictional ${ }^{5}$ levels of partner countries (see Figure 1).

FTA has been working closely with key actors in all countries that were part of the GCS REDD+ program. Program team members have worked directly with many individual actors and actor groups in government and non-government contexts, jointly developing and producing work that has often empowered local actors by helping them to become visible and respected on the national stage. The program has trained stakeholders individually and institutionally. The program team has convened journalist training. Team members have closely interacted with villagers who were both part of and subjects of the research on the impacts of local REDD+ initiatives. The team also worked with participants of multistakeholder platforms as part of a research sub-program on multilevel governance. With this broad but targeted approach (finding the approaches that were most effective in each circumstance), the GCS REDD+ program saw results that extend from the natural science realm (e.g. forest cover assessments and peatlands research) to the social and policy realms (e.g. evaluation of the impact of REDD+ on local well-being, and assessment of the opportunities for and challenges to subnational jurisdictional REDD+). Such achievements fit into the program's long-term aim to empower countries to reduce deforestation and promote sustainable development.

\footnotetext{
${ }^{5}$ Jurisdictional REDD + refers to REDD+ being implemented in a territory under legal administration (province, municipality, province, state) as opposed to project-based REDD+ implementation.
} 


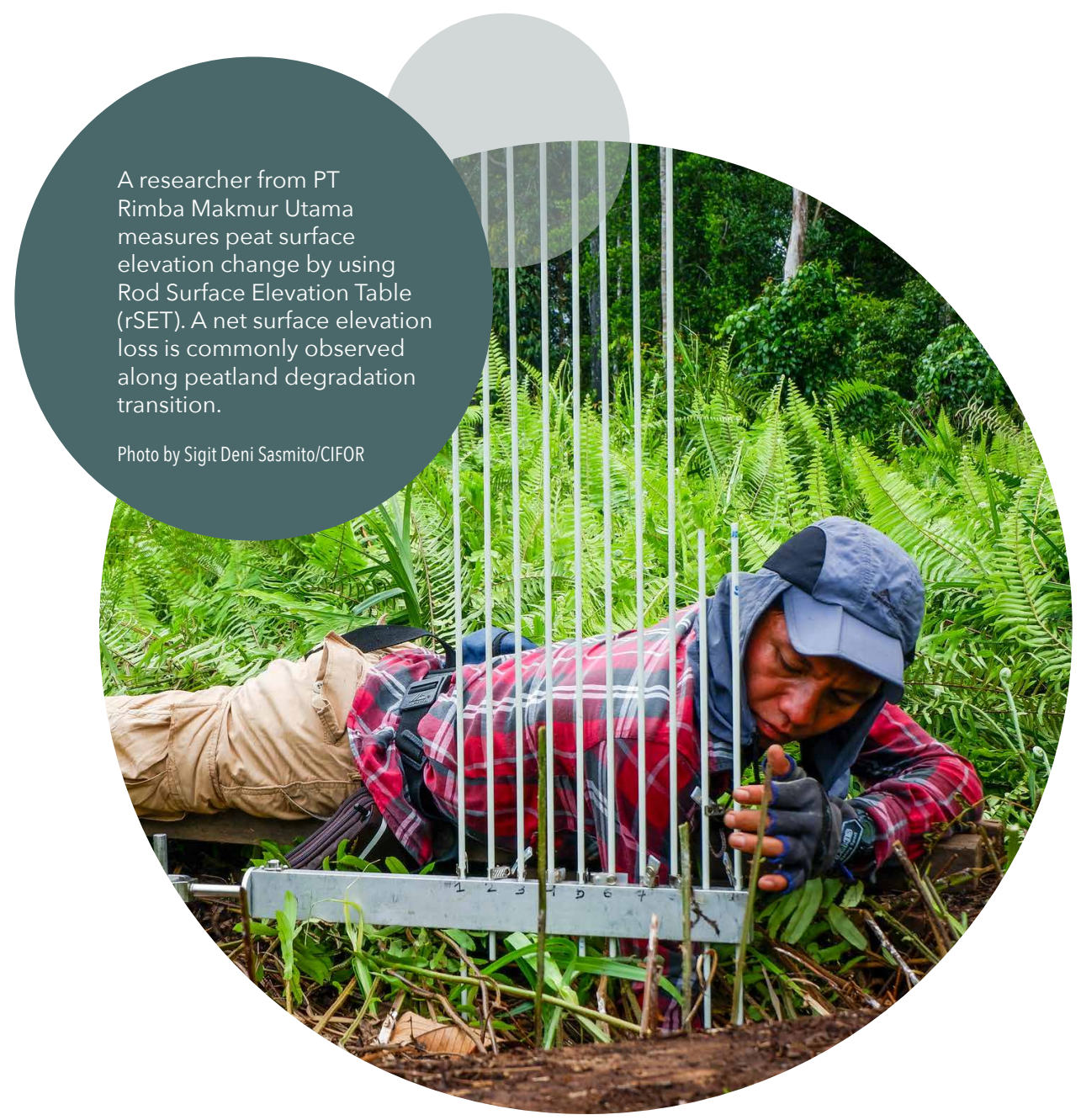

For example, GCS REDD+ has worked with Indonesia, GIFOR's host country, in many ways. This includes collaboration with the Forestry and Environmental Research, Development and Innovation Agency of the Ministry of Environment and Forestry (FOERDIA), and helping to develop the country's national REDD+ strategy. Data produced by GCS REDD+ and the complementary Sustainable Wetlands Adaptation and Mitigation Program (SWAMP) continue to inform Indonesia's forest moratorium and forest reference emission levels (see Box 1). Furthermore, CIFOR helped to set up the International Tropical Peatlands Center (ITPG), a multicountry initiative led by Indonesia with the Democratic Republic of the Congo, the Republic of the Congo and Peru. 
Box 1. Support for forest and wetlands monitoring in Indonesia

Indonesia has vast tropical forests and wetlands. It is also the fifth largest emitter of greenhouse gases (GHGs) in the world, making the country central in the global climate change battle. An Overseas Development Institute (ODI) review (Young and Bird 2015) found that work by GCS REDD+ made a significant contribution to REDD+ processes in Indonesia,

INDONESIA

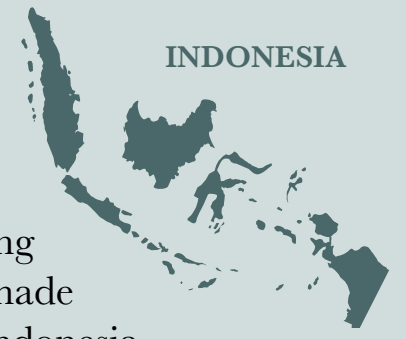
including by helping the country to become "REDD+ ready." This readiness included making available historical data on deforestation and emissions, and ensuring that policymakers and scientists engaged in a meaningful dialogue (e.g. through workshops, round-tables, training events that were organized in the program context) on how to use such data.

CIFOR programme staff were invited to become part of the team that designed the Indonesian National Carbon Accounting System (INCAS) and the country's Forest Reference Emissions Levels (FREL), providing the scientific basis to develop INCAS/FREL in the country. Although INCAS was not the final choice for an accounting system, this was a fruitful engagement on the journey towards REDD+ FREL in the country.

GCS REDD+ supported Indonesia's Peatland Restoration Agency (Badan Restorasi Gambut/BRG) in setting reference levels specific to peatland restoration, and brought together scientists and policymakers to improve the country's FREL and the national measurement, reporting and verification (MRV) system

for emissions. Tropical peatlands are one of the world's least understood and least monitored ecosystems, and scientists are working closely with decision makers to develop a roadmap for a peatland and mangrove ecosystem management strategy in Indonesia that will encompass restoration and management of the country's vast peatlands as well as its blue carbon ${ }^{6}$ ecosystems. This blue carbon - 3.14 billion metric tons in Indonesia's mangroves and 0.39 billion tons in its seagrass habitats - has global climate significance, and is under serious threat as mangroves and sea grass habitats continue to decline.

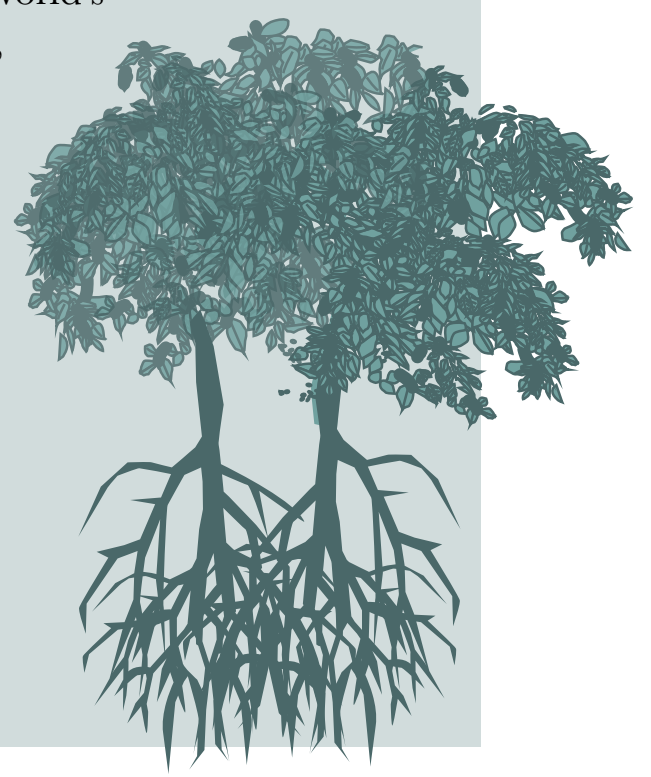

${ }^{6}$ Blue carbon is the carbon stored in marine and coastal ecosystems. 


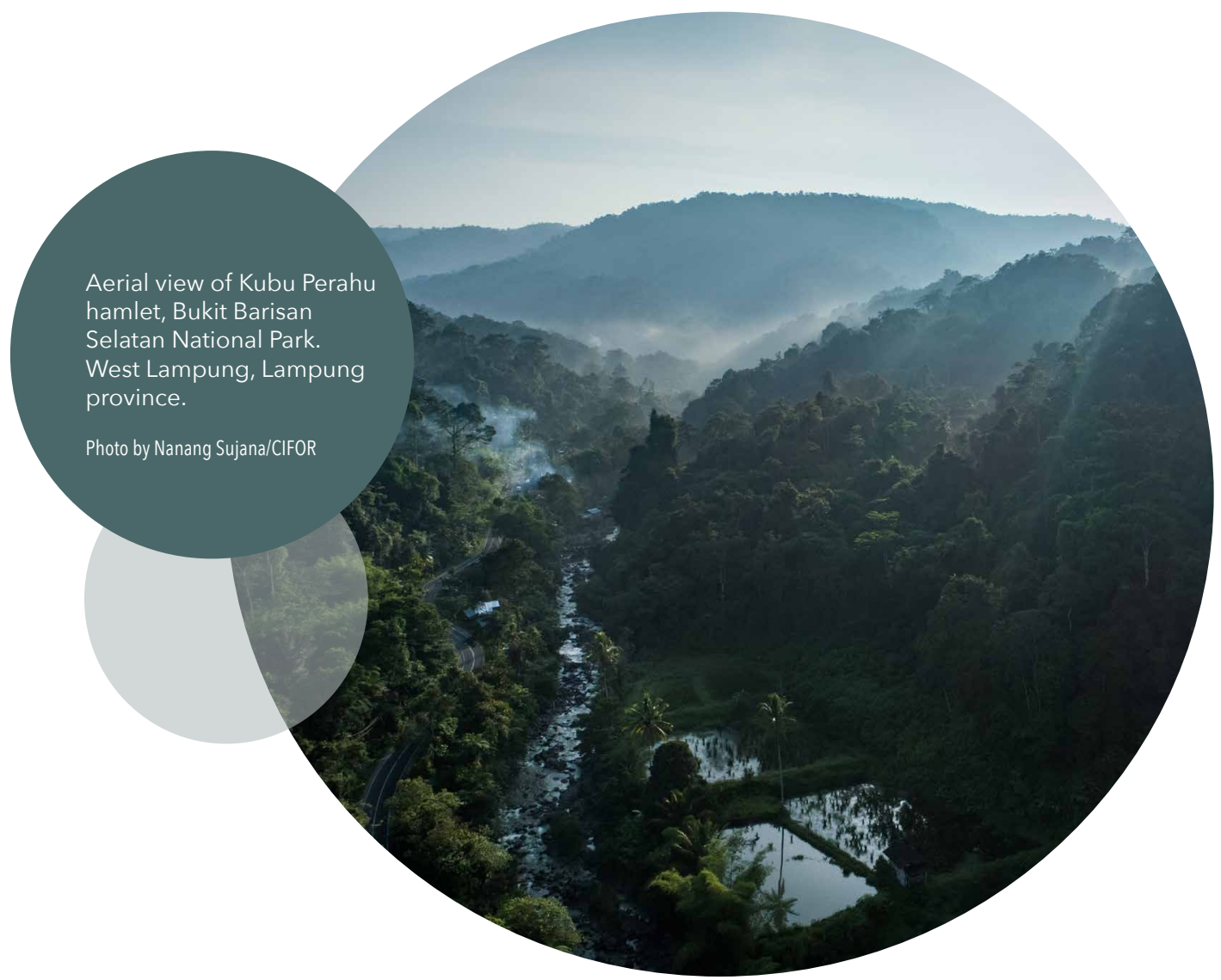

Indonesia has recently started receiving REDD+ results-based payments due to its efforts to reduce deforestation. In August 2020, the Green Climate Fund (GCF) approved USD 103.8 million to Indonesia in recognition of an avoided 20.3 million metric tons of carbon emissions between 2014 and 2016. With Indonesia having reduced emissions by 17 million tons of $\mathrm{CO}_{2} \mathrm{e}$ in 2016-17 compared to the preceding decade, the Norwegian government approved a payment of USD 56 million to the country in May 2020. Unfortunately, the long-term bilateral agreement between the two countries was terminated by Indonesia in September 2021 due to differing expectations.

In Peru, GCS REDD+ research contributed to the National Strategy on Forests and Climate Change. CIFOR's peatlands expertise and deep engagement in Peru led to the initiation of a process for the legal recognition of peatlands in the country. GIFOR's reflective learning tool for multistakeholder forums has been adapted for Peru's National Service of Natural Areas Protected by the State (SERNANP) for use with its 75 co-management committees, which govern an area covering $13.7 \%$ of the country (see Box 2). 
Box 2. Applying a participatory governance approach to protected area management in Peru

Participatory approaches are important in fostering sustainable land and resource use, and this is especially true in the REDD+ arena, where the rights of people to use forests can intersect with deforestation reduction commitments and the promise of payments. Multistakeholder forums are one way to support such an approach, bringing together a wide range of people and communities to address a common problem or to achieve a common goal. Starting in 2017, GCS REDD+ researchers have looked into the transformative potential of these forums in Brazil, Ethiopia, Indonesia and Peru, with an aim to expanding their impacts on landscape governance. This work, spanning literature reviews (Sarmiento Barletti et al. 2020b), comparative fieldwork and direct collaboration with forum participants, has resulted in 12 case studies - from West Java to Madre de Dios - that analyze the effectiveness of such dialogues and ask hard questions about equity and inclusion.

Building on this research, GCS REDD+ worked with two multistakeholder management committees for protected areas in the Peruvian Amazon and East Kalimantan, Indonesia to co-develop "How are we doing?," a tool that enables participatory reflective monitoring in multistakeholder forums (Sarmiento Barletti et al. 2020a). By supporting the participation of underrepresented actors - including Indigenous Peoples and local communities and women - in governance processes, the tool aims to improve livelihoods and encourage more effective conservation of traditional forest territories.

GIFOR worked with SERNANP in Peru to adapt and test "How are we doing?" (“Chomo vamos?”) with eight of their management committees. Given the positive reception for and widespread interest in the tool by stakeholders, SERNANP published it as one of its official documents and requires its annual implementation for its 75 protected area co-management committees. 
In Guyana and Ethiopia, engagement with government staff resulted in both countries adopting CIFOR's stepwise approach to measurement, reporting and verification of $\mathrm{GHG}$ mitigation measures (see Box 3), and the countries are continuously improving and adapting their forest and natural resource monitoring capacities with CIFOR's support.

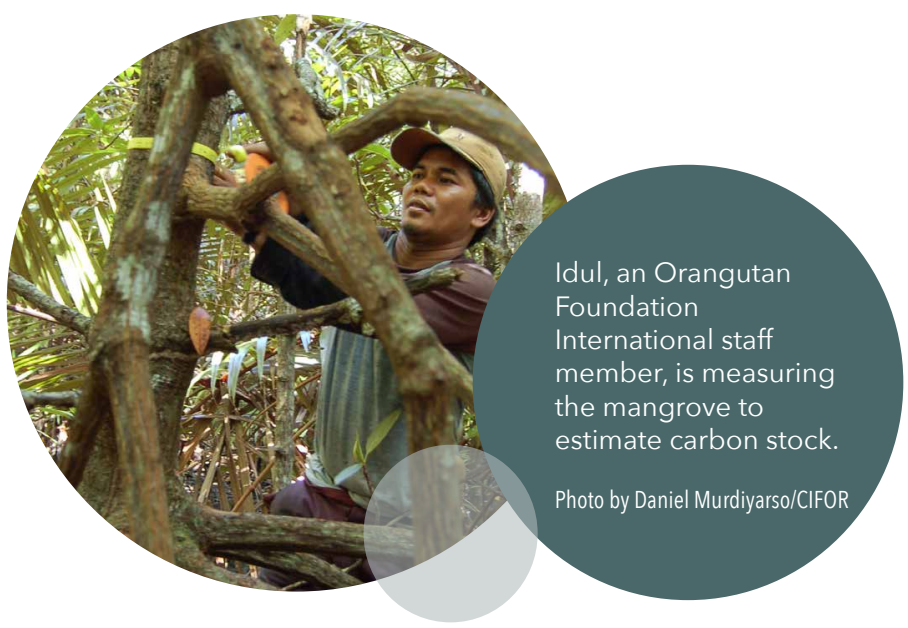

Box 3. Proposing a stepwise approach to measure and monitor carbon emissions

Through the GCS REDD+ program, FTA continues to influence global processes so that related land-use and forest protection systems are effective, efficient and equitable. One example is in measuring and monitoring emissions, where the program filled a scientific gap.

Countries have different capabilities and capacities to collect and use data on carbon emissions. IPGC guidance on measuring and creating inventories of national GHGs was not developed exclusively for the forest sector or for REDD+. GCS REDD+ identified differences in how countries were assessing forest carbon stocks, and devised adjustments for emission factors according to IPCC's tier system (Halimanjaya and Bird 2015). In 2010, GCS REDD+ scientists proposed a "stepwise approach" to measuring emissions that responds to the varying levels of national capacity. The approach offers a path for countries to move along, with three gradual steps of increasing quality in the data, as institutional and technological abilities develop.

The approach was adopted at the 2011 UNFCCC Conference of Parties (COP) in Durban, and was recognized and reaffirmed during COP19 in Warsaw in 2013, with all Parties to the UNFCGC expected to follow it. The approach has become the main method used to guide countries to improve their capacity to carry out REDD+ programmes, and is also used in setting FREL and forest reference levels.

This significant achievement has created a bridge between countries aiming to protect forests and the international REDD+ process, facilitating the production of data on emissions and therefore also the potential for payments. 
Through close work with a range of stakeholders in Vietnam, GCS REDD+ research has been instrumental - and award-winning ${ }^{7}$ — in supporting the development of a national Payment for Forest Environmental Services (PFES) policy, which was approved by the government and is being adopted by all the provinces in the country (see Box 4). In Brazil, a long-term relationship with the Government of the State of Acre resulted in a memorandum of understanding signed at UNFGCG COP25 in 2019 to continue to support social and environmental monitoring of Acre's State System of Incentives for Environmental Services. And the Government of the State of Pará drew on GCS REDD+ research findings to develop its jurisdictional REDD+ strategy in 2020.

\section{Box 4. Seeing payment success in Vietnam}

In 2008, after decades of unchecked deforestation, Vietnam launched Asia's first Payment for Forest Ecosystem Services (PFES) policy, aiming to protect forests throughout the country. PFES initiatives offer compensation to communities that sustainably manage and protect forests, and are similar to REDD+. By 2019, PFES payments accounted for $28 \%$ of total investment in the forestry sector and contributed to the funding of forest protection contracts for more than $55 \%$ of the country's forests, as the national policy is being adopted by all provinces. The success of Vietnam's PFES approach offers lessons for REDD+, not only in Vietnam but in other countries as well.

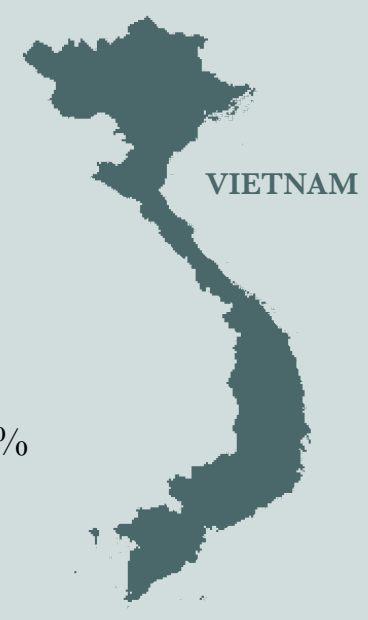

GCS REDD+ work was instrumental in supporting the development of Vietnam's PFES policy. From 2009 to 2013, researchers with GCS REDD+ assessed the country's PFES implementation, following a request by the country's Ministry of Agriculture and Rural Development. Based on those findings, the GCS REDD+ program was asked to help develop a monitoring and evaluation system and national guidelines for PFES financial management, and to analyze PFES impacts in several provinces. Civil society organizations in Dak Lak and Thua Thien Hue provinces are now monitoring PFES activities there based on GCS REDD+ research and training.

In addition to support for the national PFES policy, the GCS REDD+ program's work also informed the country's 2017 Forestry Law on the need to account for both the direct and indirect value of forests.

${ }^{7}$ In 2016, CIFOR received a Vietnam government award for its contribution to the forestry sector, notably for its work on PFES (Pham et al. 2021) 
In the Democratic Republic of the Congo, the national REDD+ coordinator requested assistance from GCS REDD+ to help evaluate REDD+ processes and progress in the country after a GCS REDD+ national stakeholders' workshop in 2019. In Ethiopia, the program provided information relevant to the development of the national REDD+ strategy and the benefit-sharing mechanism of the Oromia Forested Landscape Program.

Local stakeholders in several countries interviewed as part of project evaluations emphasized the strong engagement of GCS REDD+ with policymakers and decision makers via GCS REDD+'s focus on the coproduction of knowledge. This engagement helped foster relations and understanding that led to the uptake of research findings.

REDD+ faces many challenges, such as inadequate financial support and unresolved land tenure and user rights. These obstacles are more problematic in some countries and regions than in others. Providing evidence, capacity building and engagement to help remove such obstacles is part of the purpose of GCS REDD+, but these challenges are much larger than one project alone. Nevertheless, important lessons were learned about successful contributions, which are addressed in Section 4.

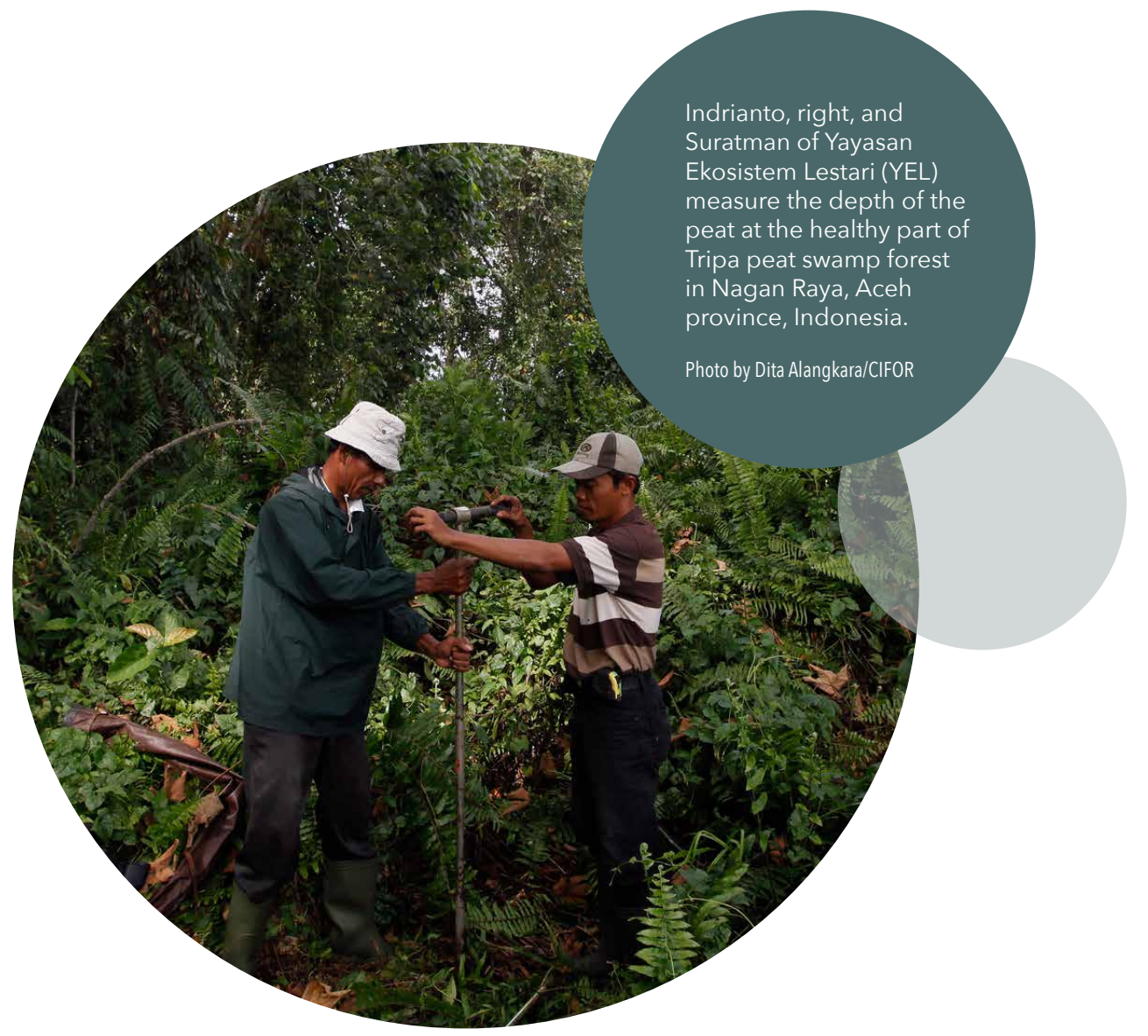




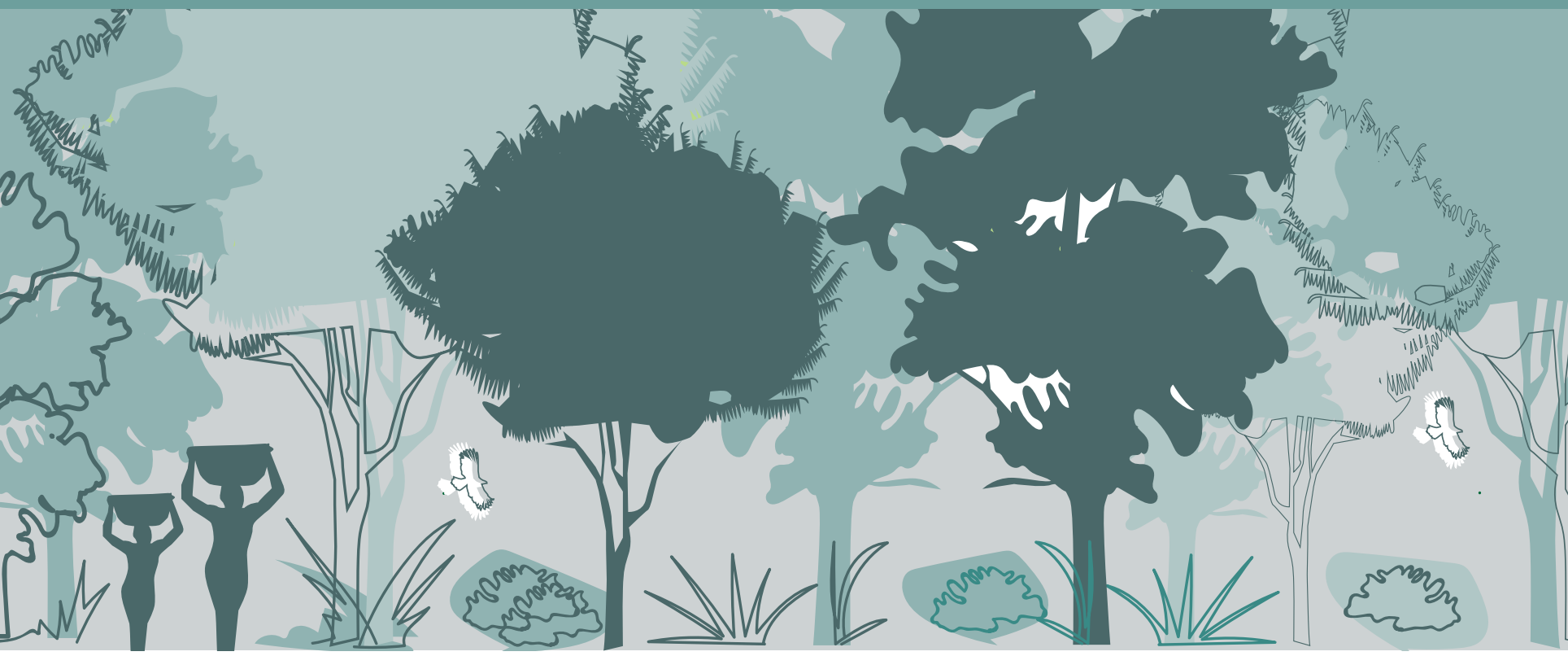

\section{Global impacts}

Through the production of knowledge, and the establishment of relationships, the GCS REDD+ program has contributed to multiple global outcomes.

GCS REDD+ experts contributed to a United Nations Framework

Convention on Climate Change (UNFCGC) decision in $2011^{8}$ recommending a stepwise approach on setting, measuring and reporting reference levels (Box 3). GCS REDD+ scientists authored several chapters in the 2013 Wetlands Supplement to the 2006 Intergovernmental Panel on Climate Change (IPCG) Guidelines for National Greenhouse Gas Inventories; the 2019 Refinement to the 2006 IPCG Guidelines for National Greenhouse Gas Inventories; and the 2019 Special Report on Climate Change and Land.

GCS REDD+ pays strong attention to the role of tenure security as a basis for REDD+, and UN-REDD made tenure part of its strategy framework based on information generated by GCS REDD+ (Young and Bird 2015). The program has also provided advice to the European Commission on transparent monitoring and REDD+ finance. In 2019, given CIFOR's experience with gender, tenure and climate change research, GCS REDD+ scientists led a training session with staff of The Tenure Facility on gender in collective tenure reforms. And the Governors' Climate \& Forests Task Force and the United Nations Development Programme (UNDP) asked CIFOR to help organize and facilitate training in gender-transformative policies and programmes for their delegates. For more information on research on gender conducted within FTA, see Highlight No. 15 in this series (Elias et al. 2021).

${ }^{8}$ https://unfccc.int/documents/7110. 


\subsection{Quantifying emissions avoided}

One way to put numbers on the effects of REDD+ is by quantifying what would happen if countries adopted the framework. GCS REDD+ has worked in six countries that together possess 55\% of global tropical forest cover: Brazil, Cameroon, the Democratic Republic of the Congo, Indonesia, Peru and Vietnam. If those countries used the

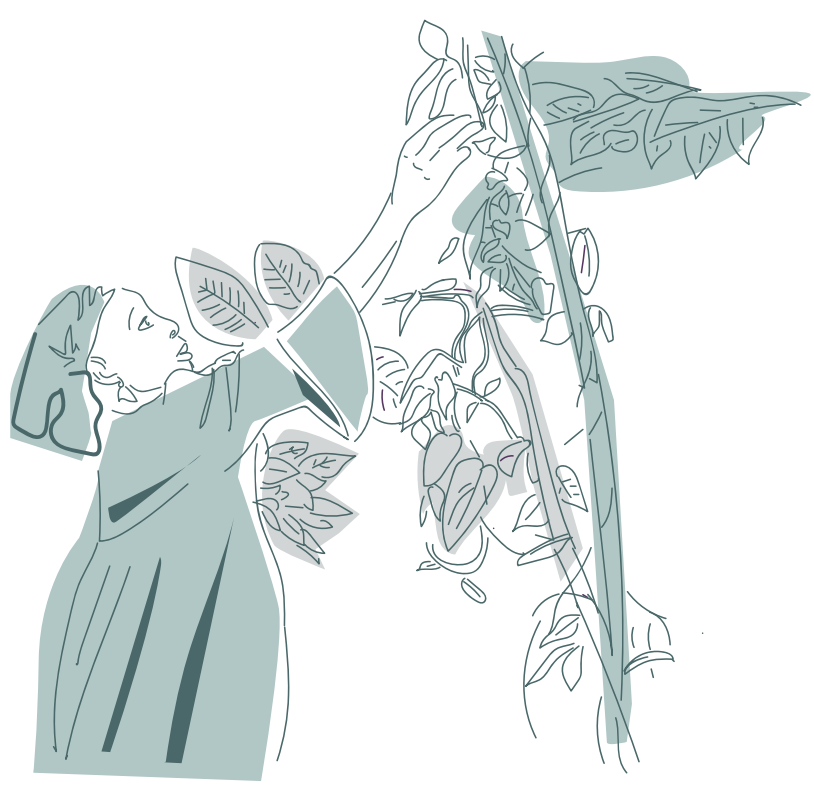
knowledge produced to inform and create successful mitigation policies, this could contribute to reducing deforestation in their countries by 10-30\%. Annually, 0.5-1.6 million ha of forests could be saved, resulting in yearly avoided emissions of approximately $0.2-0.6 \mathrm{Gt} \mathrm{CO}_{2}(5-15 \%$ of the total annual land-use emissions of $3.3 \mathrm{Gt} \mathrm{CO}_{2}$ ). This would positively affect at least half a million forest-dependent people directly, and a further 1.5 million people who depend indirectly on forest products and services.

\subsection{Developing sectoral guidance on forestry, land use and ecosystems}

In 2019, given the program's long experience in analyzing REDD+, CIFOR (together with COWI, a Danish consultancy) was selected by the Green Climate Fund (GCF) through a competitive process to develop GCF Sectoral Guidance for two of its results areas. GCS REDD+ scientists served as lead and contributing authors of the draft strategy guides for forestry and land use, and ecosystems and ecosystems services (GCF has so far not published them). These strategies include recommendations for GCF investments that build on knowledge gained from GCS REDD+ work on transformational change, climate finance, REDD+ policies and interventions, jurisdictional approaches and equity and rights. Additionally, GCS REDD+ leveraged its experience with rigorous impact evaluation of REDD+ to contribute to the LearningOriented Real-Time Impact Assessment (LORTA) initiative of the GGF Independent Evaluation Unit to assess GCF-funded projects. 
GCS REDD+ researchers also reviewed the impacts of REDD+ initiatives (Box 5).

Box 5. Building the strongest evidence base for REDD+

Given the high stakes for forest and land policies and programmes to provide both climate and development benefits, knowledge is key. Impacts can vary highly across contexts and intervention types, and therefore it is vital to have the best possible evidence base for understanding the performance of policies and actions on the ground before taking them to scale.

Despite the importance of REDD+, there has been little rigorous evaluation of its impacts (Duchelle et al. 2018). GCS REDD+ is doing this work. Researchers are evaluating the impacts of various REDD+ interventions on forest conservation, on aspects such as forest cover and land-use change, and they are looking at impacts on local livelihoods in terms of income, assets, tenure security and perceived well-being in a multi-site study.

The research focuses on 22 subnational REDD+ sites in six countries: Brazil, Cameroon, Indonesia, Peru, Tanzania and Vietnam. It combines three phases of socioeconomic surveys in 150 villages and nearly 4,000 households (including control groups) with Global Forest Change data from 2000 to 2020. The research measures the effects of REDD+ interventions on a set of common outcome indicators (Sunderlin et al. 2016). Three rounds of panel data were collected: the first round in 2010-12 (pre-intervention); the second round in 2013-14 (early postintervention); and the third round in 2018-19 (to consolidate evaluated post-intervention impacts).

This research responds to calls to reassess the impact evaluation of conservation efforts (Miteva et al. 2012; Wunder 2017) by comparing the measured conservation and livelihoods outcomes of various policy tools applied across sites, using carefully matched treatment and control localities. This evidence was used to support the Independent Evaluation Unit of the GGF in the Learning-Oriented Real-Time Impact Assessment (LORTA) of GCF-funded projects, and to provide inputs to the California Tropical Forest Standard during its public consultation process (CIFOR 2019b). 


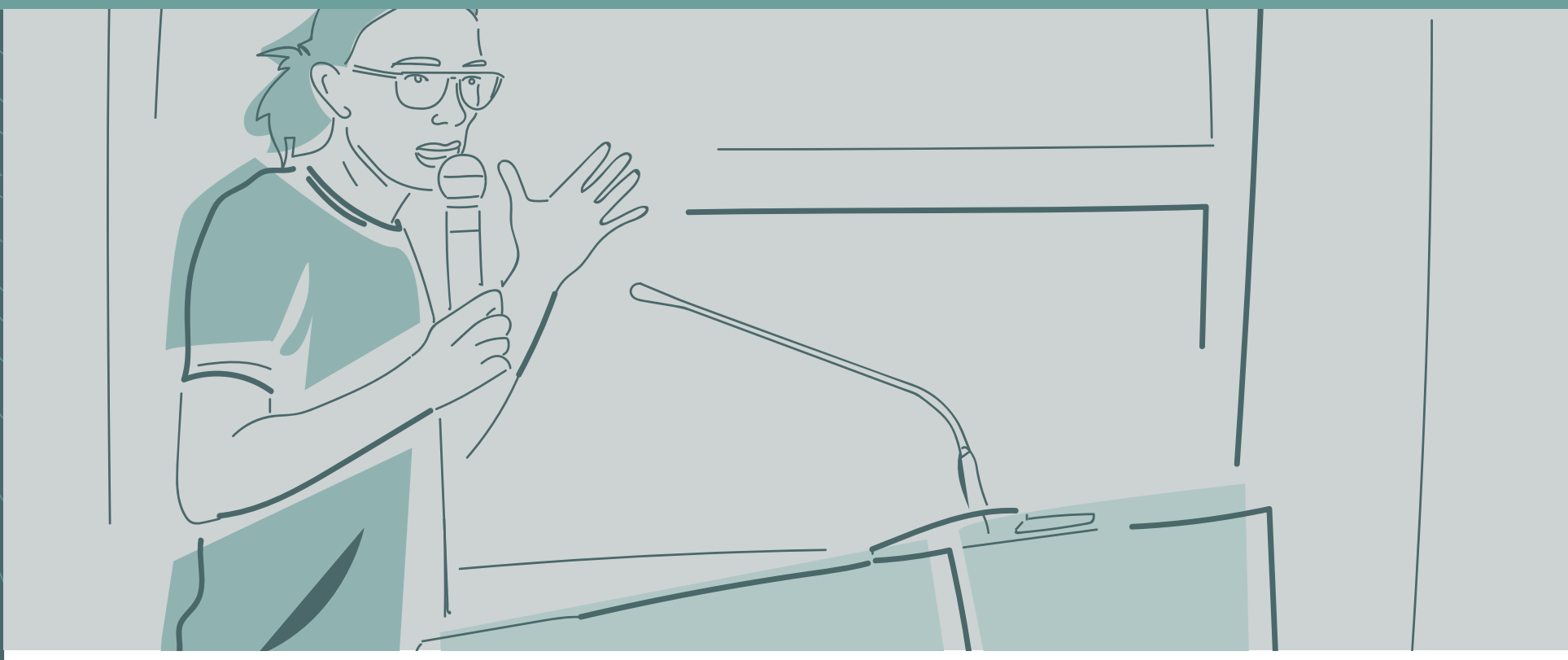

\section{Learning on how to achieve successes at scale}

As a program that aims to contribute to reduced deforestation, avoided carbon emissions and global non-carbon benefits, GCS REDD+ has necessarily - adjusted over the years. Learning from working at multiple levels with diverse stakeholders in a fast-changing global context has been adopted, with the theory of change (adapted and updated) continuing to provide the needed guideposts. An independent mid-term evaluation in 2018 (Ducenne et al. 2019) found that the program's activities were relevant to evolving country contexts and the international REDD+ agenda, stating "REDD+ is a moving - and some say elusive - target and despite shifts in terminology, broader carbon-related scope and many institutional changes, outputs from all modules remain useful globally and in the eight targeted countries" (ibid., iv).

Work of global "influencers". The 2015 ODI review (Young and Bird 2015) emphasized the role of trusted advisers of GCS REDD+ who helped to advance the REDD+ policy agenda at the global, national and subnational levels. These scientists work as experts, as brokers and as connectors to achieve impact from the research on REDD+ being done by the program. Especially in the realm of policy, it is important to have scientists playing such key roles. One of the aims of the GCS REDD+ program, as discussed earlier, is to influence land-use policy so that the conditions are right for REDD+ to be able to succeed. This means connecting researchers to policymakers and policymakers to researchers. It means close engagement with actors in the 
private sector, CSOs and research partners so that people, governments and organizations have the capacity to promote and enable the implementation of REDD+ activities.

This is something that global GCS REDD+ "influencers" have been doing successfully.

CIFOR principal scientist Daniel Murdiyarso is one example, making the right connections and thereby influencing the design of Indonesia's systems for calculating FREL. This has in turn helped to break new ground in policy on international climate change. Being a respected scientist and having held senior positions at the Indonesian Ministry of Environment and Forestry mean that Murdiyarso is uniquely qualified and experienced to be such an influencer.

Another global influencer is William Sunderlin, who helped to get land tenure onto the UN-REDD agenda, where it had not been initially. Sunderlin worked to convince the UN-REDD Policy Board to take up the land tenure issue and to make it more of a priority. All his efforts were based on GCS REDD+ research. Kristell Hergoualc'h of CIFOR and Martin Herold of Wageningen University are global influencers on the technical and policy side, having contributed to global MRV protocols and IPCG reports, and working closely with national partners in Peru and Guyana.

These are just a few examples of the many GCS REDD+ scientists who have served as influencers on a range of REDD+-related topics at multiple levels.

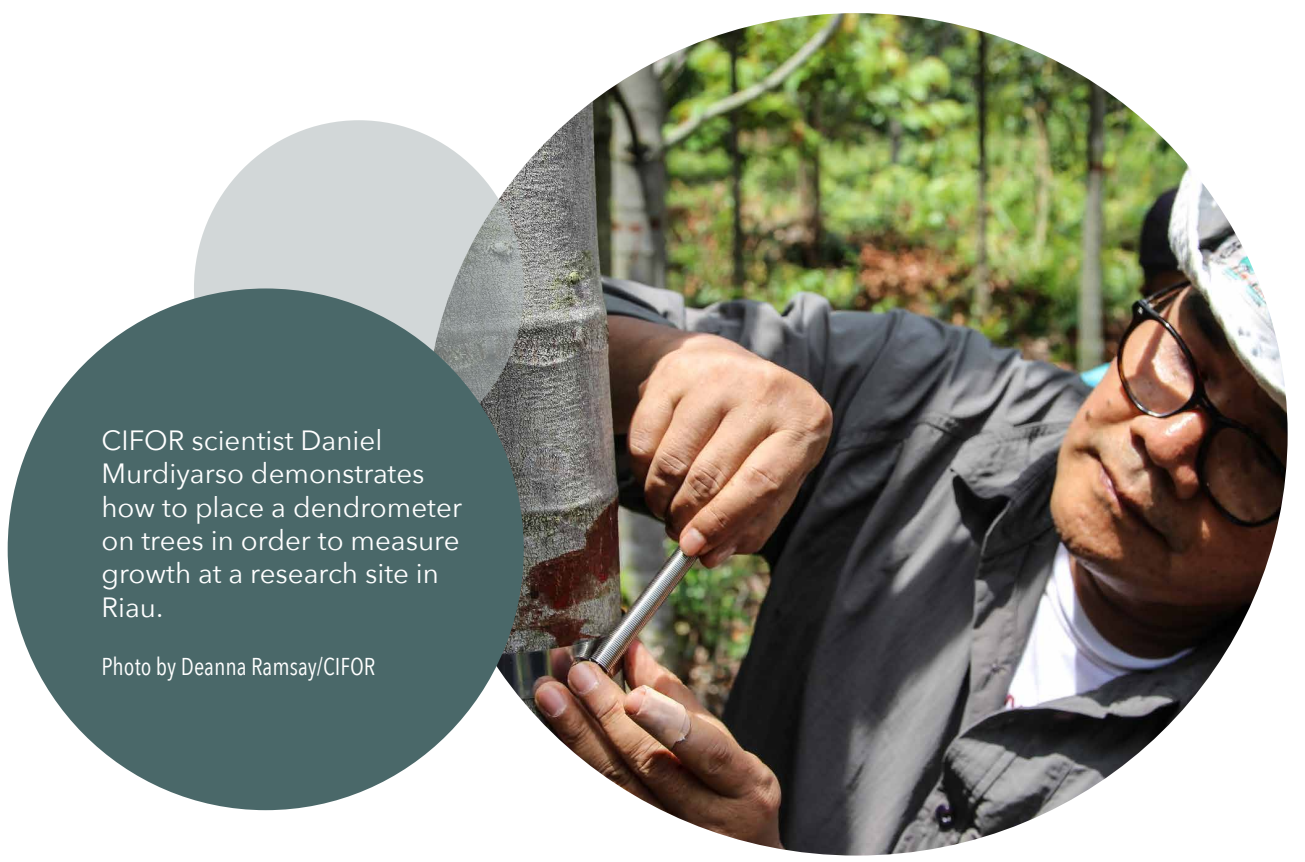


Agility is required to respond to new policy priorities. The need for agility and relevance when working in an ever-changing research and policy environment is clearly central to REDD+-related efforts, and longterm, somewhat flexible funding for GCS REDD+ has allowed the program to adjust as necessary.

There are always certain risks and assumptions related to the achievement of outcomes, including policymakers and planners who continue to be swayed by prevalent patterns of political and economic interests that underpin the widespread conversion of tropical forests. Two inter-related risks were the most difficult to manage. First, in many tropical forest countries there is no strong political will to adopt a broad agenda that tackles deforestation and forest degradation. Second, policy swings or changes in personnel in implementing agencies at the national and subnational level can impede meaningful and sustainable progress, and hinder policy engagement.

These challenges were dealt with by adjusting stakeholder engagement strategies. For example, in Brazil, given the backsliding on the environmental agenda at the national level, GCS REDD+ focused on the subnational governments that were filling the void in environmental leadership. In Indonesia, opportunities were found in the renewed political will of the national government to reduce deforestation; GCS REDD+ responded to key technical needs (e.g. national FREL development) while supporting provincial and district-level governments in their land-use strategies. In all countries where GCS REDD+ works, diversifying engagement strategies with government agencies, civil society organizations, grassroots organizations, national research institutes and media actors helped mitigate some of the underlying political challenges.

Partnerships and presence on the ground. Across various countries and cultures and amid complicated national situations, GCS REDD+ achievements are closely tied to successful in-country partnerships. The program has seen more success where it has a strong on-the-ground presence, including in Indonesia, where CIFOR is based. The 2015 ODI assessment looked at effects in REDD+ countries where GCS REDD+ had less of a presence, which emphasized the need for practical local support in order to be most effective (Young and Bird 2015). The 2018 mid-term assessment of GCS REDD+ (Ducenne et al. 2019) echoed this recommendation, noting stakeholder requests for more research on the ground. The $2021 \mathrm{Efeca}$ evaluation (Efeca 2021) noted that uptake of research and policy influence was limited in countries with no GIFOR presence, and recommended 


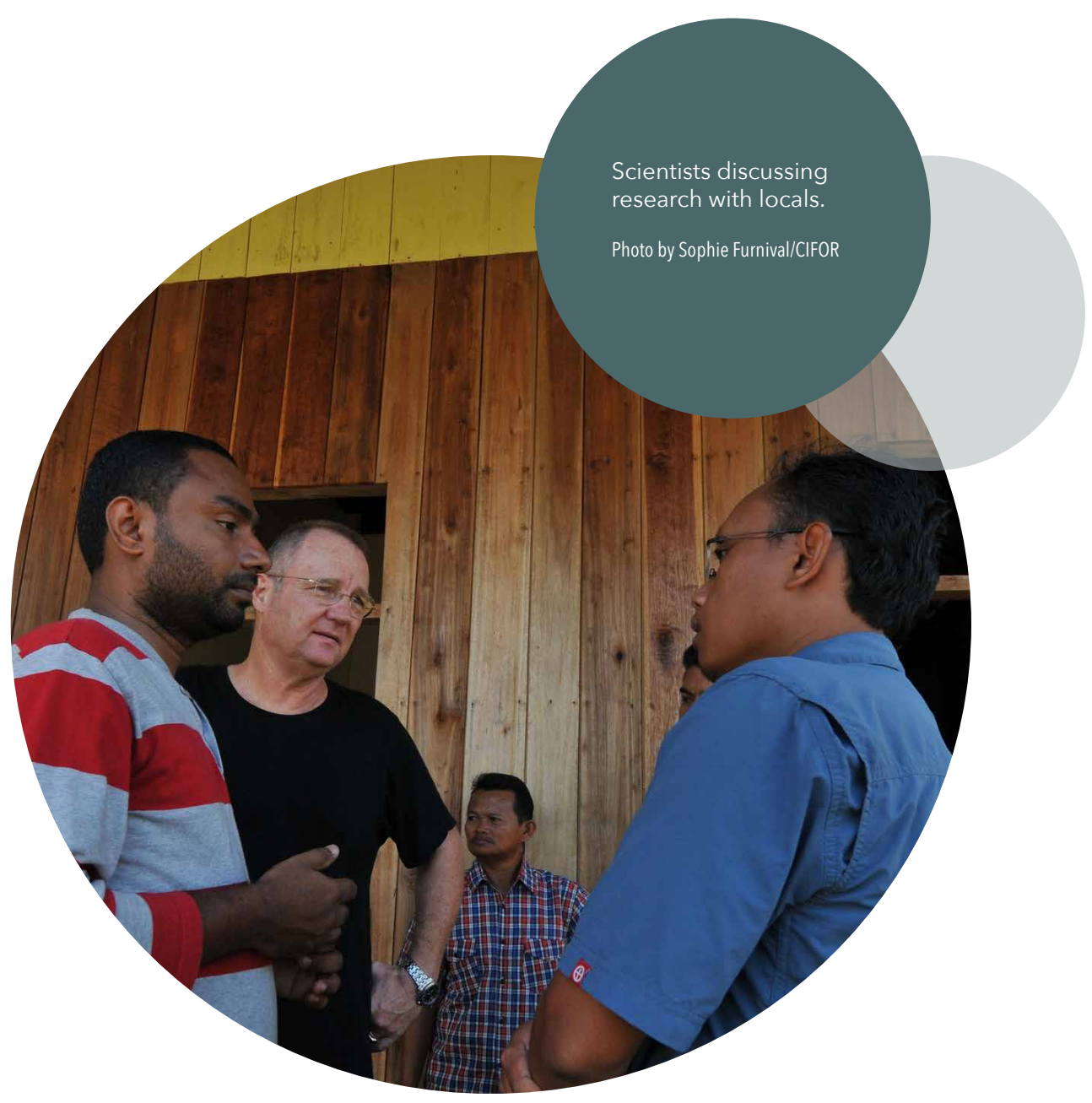

holding events and workshops in those countries, as well as developing more targeted and tailored products.

\section{Greate research-based communications for various audiences.}

The need for increased access to publications was commented on by several country-level stakeholders in the 2021 Efeca evaluation. As discussed throughout this Highlight, research outputs are not enough. Stakeholder engagement is key for buy-in. To best engage and influence, and to ensure that research is understood, a variety of materials should be produced for diverse, and different, audiences. This means scientific and technical publications should be coupled with other communication materials with clear, simple messages and practical recommendations. And these items are needed in local languages. 
Research and influence take time. In the various evaluations of the GCS REDD+ program, many stakeholders have noted the challenge of frequent changes in personnel at government agencies, particularly when restructuring occurs. In effect, GCS REDD+ researchers often have to start again when turnover occurs, and then need time to rebuild collaboration and trust.

In addition, policymakers and planners can be swayed by the prevailing political and economic interests that affect tropical forests. Developing rapport and enhancing scientific knowledge is a time-consuming process, as is the creation of politically sustainable decisions. There may be little political will in tropical forest countries to move towards an agenda that tackles deforestation and forest degradation. And policy swings and personnel changes at agencies and at the subnational and national levels can slow, prevent or even reverse progress and engagement.

\section{Be prepared for unintended consequences, both negative and}

positive. Some outcomes that have emerged during the course of the GCS REDD+ program were either not anticipated or were realized through spin-off activities. For example, involvement in the GCF sectoral guides and the FREL revisions in Indonesia and Peru, along with responses to a diverse set of stakeholder requests for information, happened because national or global actors were searching for support and found it in GCS REDD+ and CIFOR. Among the positive outcomes was the 2019 creation of the International Tropical Peatlands Center (ITPC), a true South-South collaboration with strong support from CIFOR. The program's close involvement in this initiative was based on CIFOR's recognized expertise in peatlands across the tropics. Through its longevity and breadth of expertise, and its recognition as a credible and relevant actor in REDD+ policy, GCS REDD+ had the flexibility to respond to requests, new partnerships and new initiatives swiftly and appropriately. Of course, a certain degree of serendipity may be innate to every success story.

With a theory of change that recognizes that, ultimately, national partners are responsible for achieving results and creating impact, it is also necessary to recognize that development work can experience delays and detours. It is the partners that implement change, and they work under a range of pressures and within other hierarchies and may have timelines that are incompatible with short project schedules. The stable, long-term funding associated with the GCS REDD+ program has allowed researchers the flexibility needed to adapt to the constantly evolving REDD+ agenda and cultivate strong partnerships over time. 
Cost-efficiency is key. The international community has disbursed roughly USD 1 billion for REDD+ every year between 2008 and 2015 (Boettcher et al. 2018), and even more since. In contrast, GCS REDD+ has cost approximately USD 2 million per year between 2016 and 2020 in its third phase. Disregarding the different time periods for these two amounts, the program budget corresponds to about $0.2 \%$ of the finance disbursed internationally to REDD+. With this budget, GCS REDD+ has produced more than 530 publications and 17 databases, and held 64 capacity development events and many workshops and online sessions. For more information on capacity development conducted within FTA, see Highlight No. 16 in this series (Wardell et al. 2021).

More than 6,800 people received some form of training from GCS REDD+, and there were close interactions with REDD+ stakeholders globally and in eight tropical forest countries so that REDD+ policies and practices could be made more efficient, effective and equitable. While it is impossible to put numbers on the increase in efficiency for national and international REDD+ processes due to GCS REDD+, the outcomes suggest that the program has made a substantial contribution.

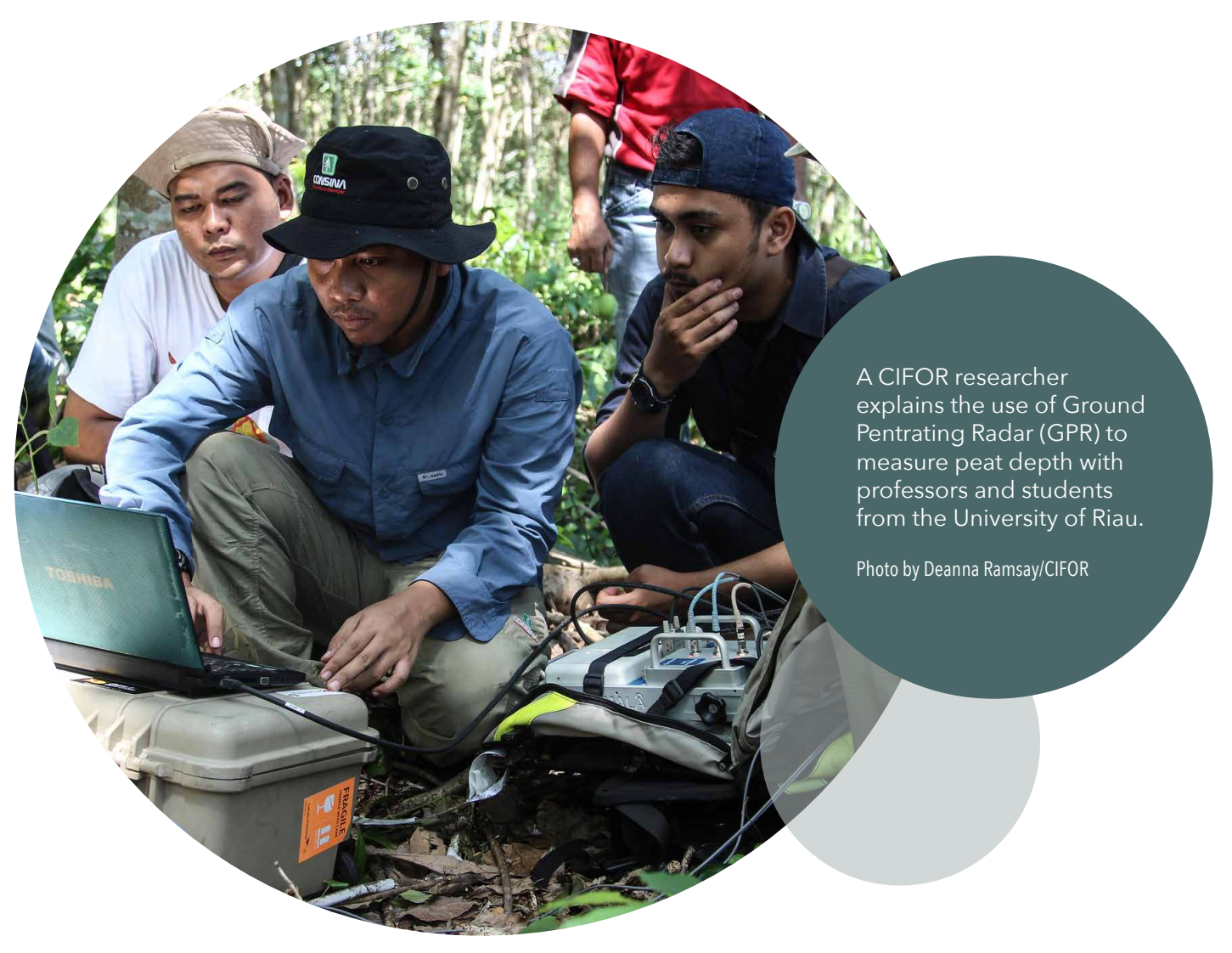




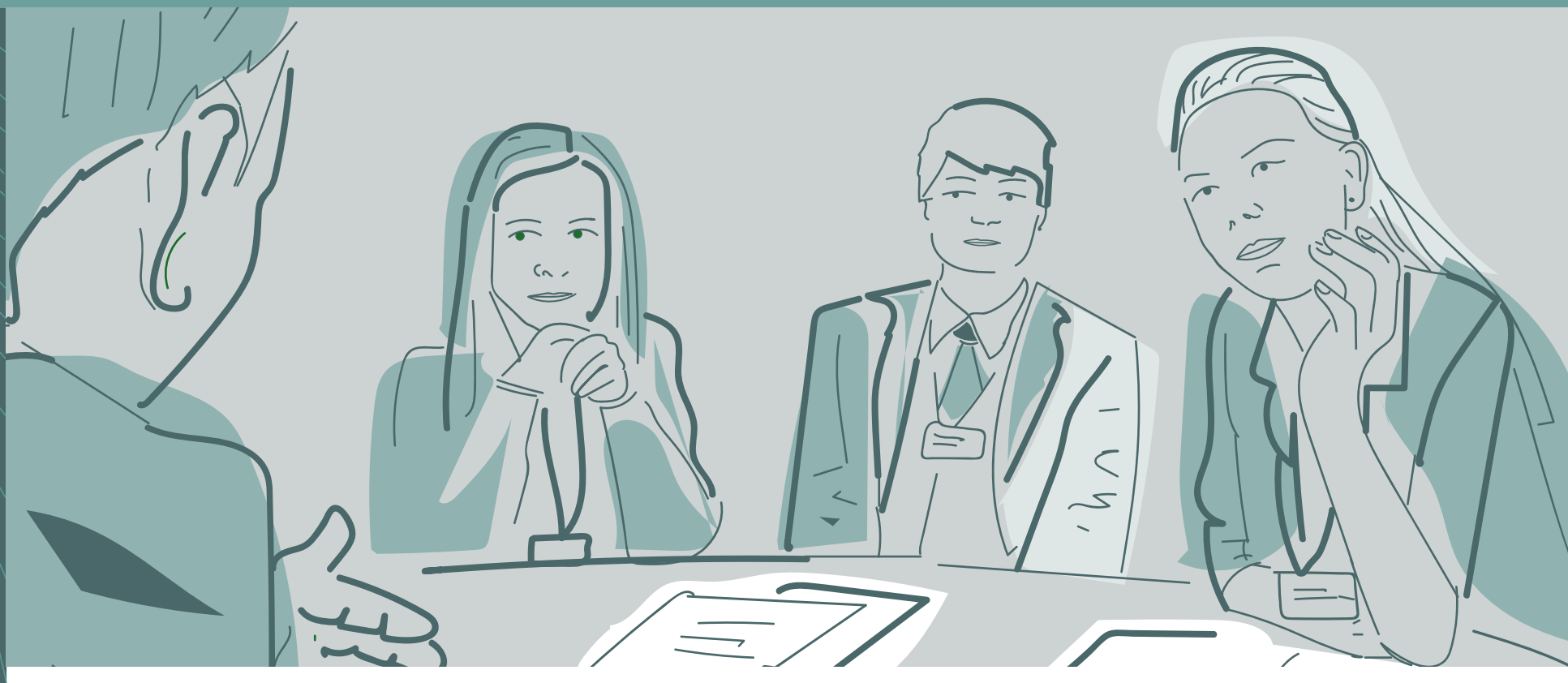

\section{Conclusions}

Ultimately, for REDD+ to be successful, a transition away from the forces that drive, maintain and intensify business-as-usual deforestation and forest degradation is needed. Such a transition is required both within and beyond the forestry sector, and also beyond the policy domains of tropical countries where deforestation takes place.

Successful research for development on REDD+ necessarily includes many lessons learned, including the need for country offices and on-the-ground engagement, awareness of the time needed to effect change at the policy level and with decision makers, and the agility to respond to a host of factors that affect how land is used.

Even with a clear theory of change mapping pathways to impact, working on climate change includes unplanned results and an element of serendipity. This stands alongside the GCS REDD+ program's continuing co-production of knowledge to inform decision makers, and the continuing work to develop trust in that science by partners. The time spent by the GCS REDD+ team to co-develop and present research outputs with in-country decision makers paid off, and twelve programme outcomes from the third phase were achieved (Efeca 2021). And, in all priority countries, activities were identified by evaluators that contributed to policy and practice change at various levels by informing and, to a certain extent, influencing policymakers and practitioners. 
The GCS REDD+ aim is to develop sound scientific knowledge on REDD+, and to equip in-country partners with this knowledge so they can initiate change in their countries. By empowering partners to access, understand, become part of, document and disseminate the program's findings on $\mathrm{REDD}+$, a solid base is being built for sustained achievements into the future.

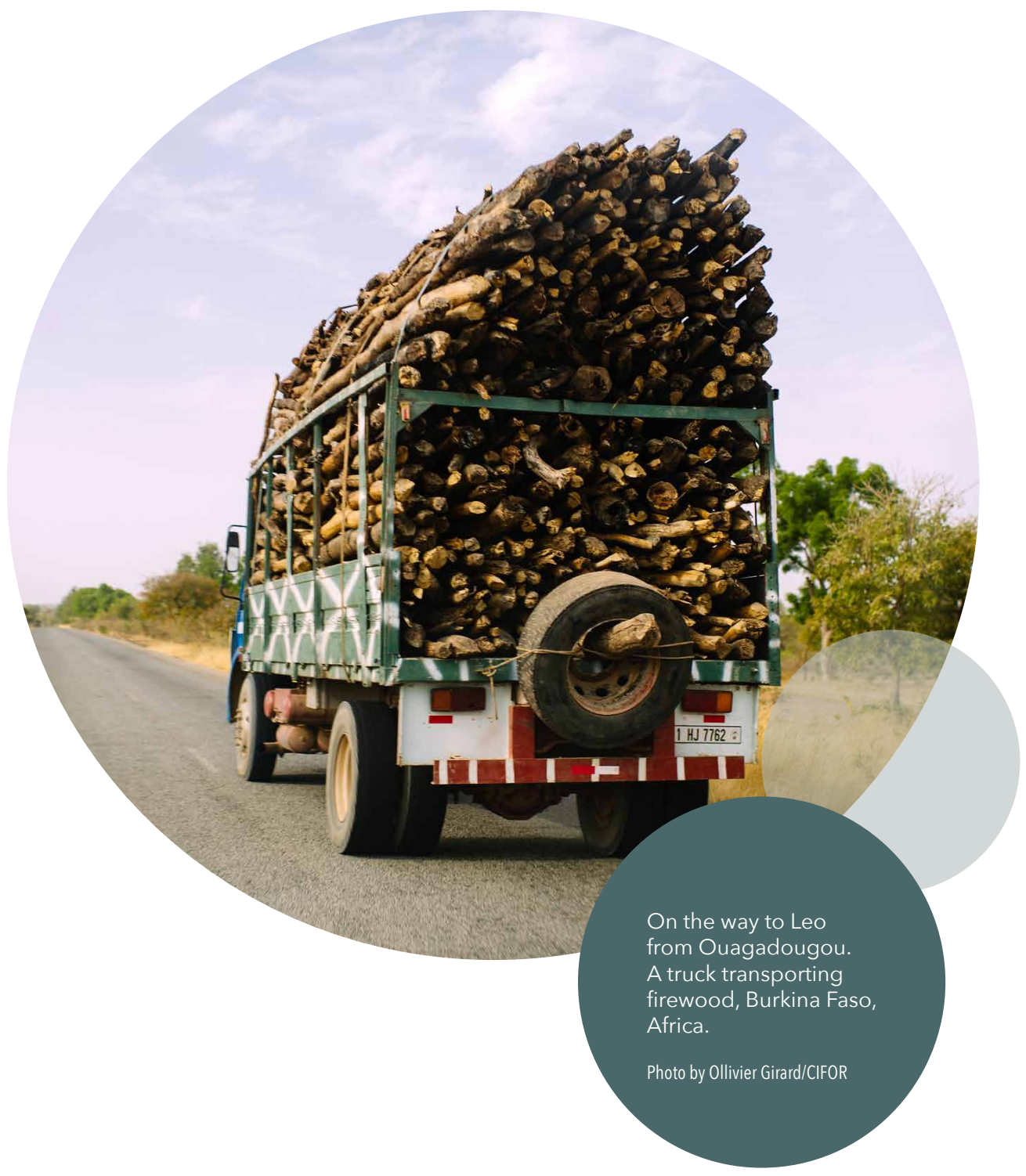




\section{References}

Angelsen A, Brockhaus M, Duchelle AE, Larson A, Martius C, Sunderlin WD, Verchot L, Wong G and Wunder S. 2017. Learning from REDD+: A response to Fletcher et al. Conservation Biology 31:718-720. https://doi.org/10.1111/cobi.12933.

Angelsen A, Duchelle A, Pham TT, de Sy V, Larson A and Martius C. eds. 2018a. Transforming REDD+: Lessons and new directions. Bogor, Indonesia: CIFOR. https://doi.org/10.17528/cifor/007045.

Angelsen A, Martius C, De Sy V, Duchelle AE, Larson AM, Pham TT. 2018b. Conclusions: Lessons for the path to a transformational REDD+. Bogor, Indonesia: CIFOR. https://www.cifor.org/knowledge/publication/7076/.

Atmadja SS, Duchelle AE, De Sy V, Selviana V, Komalasari M, Sills EO and Angelsen A. in press. How do REDD+ projects fit the goals of the Paris Agreement? Environmental Research Letters.

Boettcher H, Herrmann LM, Herold M, Romijn E, Román-Cuesta RM, Avitabile V, De Sy V, Martius C, Gaveau DLA, Fritz S, et al. 2018. Independent monitoring: Building trust and consensus around GHG data for increased accountability of mitigation in the land use sector. Luxembourg: Publications Office of the European Union.

https://doi.org/10.2834/513344.

CIFOR (Center for International Forestry Research). 2019b. REDD+ addresses climate stability and sustainable development objectives. CIFOR letter to California Air Resources Board, 29 Aug 2019. https://www.arb.ca.gov/lispub/comm/bccomdisp. php?listname $=t \mathrm{ts} 2019 \&$ comment_num $=89 \&$ virt_num $=87$.

Ducenne Q, Bourland N, James A, Veron P and, Devaux S. 2019. A global comparative study for achieving effective, efficient and equitable REDD+ results 2016-2020: Midterm review 2018. Final Report. https://www2.cifor.org/gcs/wp-content/uploads/sites/14/2020/02/ CIFOR-GCS-REDD-project_Mid-Term-Review_2019.pdf.

Duchelle AE, Simonet G, Sunderlin WD and Wunder S. 2018. What is REDD+ achieving on the ground? Current Opinion in Environmental Sustainability 32:134-140. https://doi.org/10.1016/j.cosust.2018.07.001.

Duchelle AE, Seymour F, Brockhaus M, Angelsen A, Larson AM, Moeliono M, Wong GY, Pham TT and Martius C. 2019. Forest-based climate mitigation: Lessons from REDD+ implementation. https://www.cifor.org/knowledge/publication/7428/.

Efeca. 2021. Final Evaluation Report for CIFOR's “A Global Comparative Study for achieving effective, efficient and equitable REDD+ results." Bogor, Indonesia: CIFOR. https://www2.cifor.org/wp-content/uploads/sites/14/2021/06/GCS-Part-1-FinalEvaluation-Report-2021.pdf. 
Griscom, B.W., Adams, J., Ellis, P.W., Houghton, R.A., Lomax, G., Miteva, D.A., Schlesinger, W.H., Shoch, D., Siikamäki, J.V., Smith, P. and Woodbury, P., 2017. Natural climate solutions. Proceedings of the National Academy of Sciences, 114(44), pp.1164511650. http://www.pnas.org/content/early/2017/10/11/1710465114.

Griscom, B.W., Busch, J., Cook-Patton, S.C., Ellis, P.W., Funk, J., Leavitt, S.M., Lomax, G., Turner, W.R., Chapman, M., Engelmann, J. and Gurwick, N.P., 2020. National mitigation potential from natural climate solutions in the tropics. Philosophical Transactions of the Royal Society B, 375(1794), p.20190126. https://royalsocietypublishing.org/doi/10.1098/rstb.2019.0126.

Halimanjaya A and Bird N. 2015. Global case study: The development and promotion of the stepwise approach to establishing forest reference levels. London: Overseas Development Institute.

IPCG, 2019. Summary for Policy Makers - IPCG, 2019: Summary for Policymakers. In: Climate Change and Land: an IPCG special report on climate change, desertification, land degradation, sustainable land management, food security, and greenhouse gas fluxes in terrestrial ecosystems [P.R. Shukla, J. Skea, E. Calvo Buendia, V. Masson-Delmotte, H.O. Pörtner, D. G. Roberts, P. Zhai, R. Slade, S. Connors, R. van Diemen, M. Ferrat, E. Haughey, S. Luz, S. Neogi, M. Pathak, J. Petzold, J. Portugal Pereira, P. Vyas, E. Huntley, K. Kissick, M. Belkacemi, J. Malley, (eds.)]. https://www.ipcc.ch/srccl/.

Martius C, Angelsen A, Larson AM, Pham TT, Sonwa DJ and Belcher B. 2018. Pathway to impact. Is REDD+ a viable theory of change? In Angelsen A, Martius C, Duchelle A, Larson AM, De Sy V and Pham TT. eds. 2018. Transforming REDD+. Bogor, Indonesia: CIFOR. https://www.cifor.org/knowledge/publication/7062.

Miteva, D.A., Pattanayak, S.K., Ferraro, P.J., 2012. Evaluation of biodiversity policy instruments: what works and what doesn't? Oxford Review of Economic Policy 28, 69-92. https://doi.org/10.1093/oxrep/grs009.

Pham, T.T., Ngoc, T.B.D., Thürer, T., O’Connell, E., 2021. Payments for Forest Environmental Services in Viet Nam. Strengthening effectiveness through monitoring and evaluation (No. 327), GFOR InfroBrief. CIFOR. https://www.cifor.org/publications/ pdf_files/infobrief/8028-infobrief.pdf.

Roe, S., Streck, C., Obersteiner, M., Frank, S., Griscom, B., Drouet, L., Fricko, O., Gusti, M., Harris, N., Hasegawa, T., Hausfather, Z., Havlík, P., House, J., Nabuurs, G.-J., Popp, A., Sánchez, M.J.S., Sanderman, J., Smith, P., Stehfest, E., Lawrence, D., 2019. Contribution of the land sector to a $1.5^{\circ} \mathrm{C}$ world. Nature Climate Change 9, 817-828. https://doi.org/10.1038/s41558-019-0591-9.

Sarmiento Barletti JP, Larson AM, Cisneros N, Heise N, Liswanti N, Mariño H and Tamara A. 2020a. How are we doing? A tool to reflect on the process, progress and priorities of your multi-stakeholder forum. Bogor, Indonesia: CIFOR. https://doi.org/10.17528/cifor/007796. 
Sarmiento Barletti JP, Larson AM, Hewlitt C, Delgado D. 2020b. Designing for engagement: A realist synthesis review of how context affects the outcomes of multistakeholder forums on land use and/or land-use change. World Development 127:104753. https://doi.org/10.1016/j.worlddev.2019.104753.

Sunderlin WD, Larson AM, Duchelle AE, Sills EO, Luttrell C, Jagger P, Pattanayak SK, Cronkleton P, Ekaputri AD, de Sassi C, et al. 2016. Technical guidelines for research on REDD+ subnational initiatives. 2nd edition. Bogor, Indonesia: CIFOR.

https://www.cifor.org/knowledge/publication/6009/.

Sunderlin, W.D., Sills, E.O., Duchelle, A.E., Ekaputri, A.D., Kweka, D., Toniolo, A., Ball, S., Doggart, N., Pratama, C.D., Padilla, J.T., Enright, A., Otsyina, R.M., 2015. REDD+ at a critical juncture: assessing the limits of polycentric governance for achieving climate change mitigation. International Forestry Review 17(4), 400-413.

https://doi.org/10.1505/146554815817476468.

Wunder, S., 2017. Towards Conservation Impact Evaluation 2.0. GIFOR Forests News. URL https://forestsnews.cifor.org/50603/towards-conservation-impact-evaluation-20 ? fnl $=$.

Young J and Bird N. 2015. Informing REDD+ policy: An assessment of CIFOR's Global Comparative Study. London: Overseas Development Institute. https://www.cifor.org/knowledge/publication/6021/. 


\title{
Annex 1: Program evaluation reports and links
}

\author{
Evaluation of GGIAR Research Program on Forests, Trees, and Agroforestry \\ (FTA), 2013 \\ IEA (Independent Evaluation Arrangement). 2014. Evaluation of CGLAR Research Program \\ on Forests, Trees, and Agroforestry (FTA). Rome: Independent Evaluation Arrangement of the \\ CGIAR. https://cas.cgiar.org/evaluation/publications/crp-evaluation-forests-trees-and- \\ agroforestry-fta.
}

FTA. 2014. Management response and action plan. Bogor, Indonesia: CGIAR Research Program on Forests, Trees and Agroforestry (FTA). https://cas.cgiar.org/sites/default/files/pdf/FTAManagement-response-to-Evaluation_4SEP.pdf.

CGIAR. 2014. Consortium's response to FTA's external review. Bogor, Indonesia: CGIAR. https://cas.cgiar.org/sites/default/files/pdf/Consortium-Response.FTA-EvaluationFinal.pdf.

Assessment of GIFOR's Global Gomparative Study on GDS-REDD+, 2014 Young J and Bird N. 2015. Informing REDD+ policy: An assessment of CIFOR's Global Comparative Study. London: Overseas Development Institute.

https://www.cifor.org/knowledge/publication/6021/.

Phase 3 GGS-REDD+ midterm review 2019

Ducenne Q, Bourland N, James A, Veron P and, Devaux S. 2019. A global comparative study for achieving effective, efficient and equitable REDD+ results 2016-2020: Midterm review 2018. Final Report. https://www2.cifor.org/gcs/wp-content/uploads/sites/14/2020/02/ CIFOR-GCS-REDD-project_Mid-Term-Review_2019.pdf.

CIFOR (Center for International Forestry Research). 2019a. Mid-term review of GCS REDD+: CIFOR's management response, December 2019. Bogor, Indonesia: CIFOR. https://www2.cifor.org/gcs/wp-content/uploads/sites/14/2020/02/Midterm-Reviewof-GCS-REDD_CIFOR \%E2\%80\%99s-Management-Response.pdf.

Phase 3 final evaluation, 2020

Efeca. 2021. Final Evaluation Report for CIFOR's "A Global Comparative Study for achieving effective, efficient and equitable REDD+ results." Bogor, Indonesia: CIFOR.

https://www2.cifor.org/wp-content/uploads/sites/14/2021/06/GCS-Part-1-FinalEvaluation-Report-2021.pdf.

CIFOR (Center for International Forestry Research). 2021. Final review of the Global Comparative Study on REDD+ (GCS REDD+): CIFOR's management response, fune 2021. Bogor, Indonesia: CIFOR. https://www2.cifor.org/wp-content/uploads/sites/14/2021/06/ CIFOR-management-letter_GCS-REDD-final-evaluation-report.pdf. 


\section{The FTA Highlights series}

1. Introduction: Ten Years of Forests, Trees and Agroforestry Research in Partnership for Sustainable Development

2. Tree Seed and Seedling Systems for Resilience and Productivity

3. Conservation of Tree Biodiversity and Sustainable Forest Management

4. Forest and Landscape Restoration

5. Food Security and Nutrition

6. Wild Meat

7. Trees on Farms to Improve Livelihoods and the Environment

8. Biomass, Bioenergy and Biomaterials

9. Improving Rural Livelihoods through Supporting Local Innovation at Scale

10. Sustainable Value Chains, Finance and Investment in Forestry and Tree Commodities

\section{REDD+: Combating Glimate Change with} Forest Science

12. Adaptation to Climate Change with Forests, Trees and Agroforestry

13. Multifunctional Landscapes for Sustainable Development

14. Governing Forests, Trees and Agroforestry for Delivering on the SDGs

15. Advancing Gender Equality and Social Inclusion

16. Capacity Development

17. Monitoring, Evaluation, Learning and Impact Assessment

18. The Way Forward

This list represents the order of the volumes in the series and not the time sequence of publication. 



\section{REDD+: Combating Glimate Change with Forest Science}

Over the last decade, the CGIAR Program on Forests, Trees and Agroforestry (FTA) has supported policymakers, development practitioners and communities with relevant scientific evidence to design effective, efficient and equitable REDD+ initiatives. This publication presents key FTA outputs and outcomes within the REDD+ domain in the decade from 2011 to 2021.

DOI: $10.17528 /$ cifor/008221

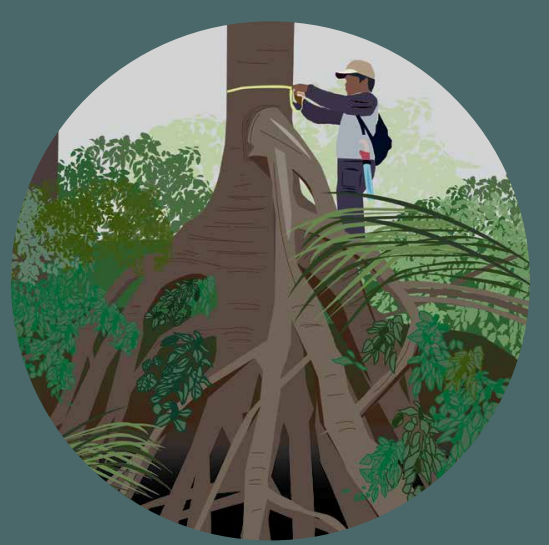

This is No. 11 of the FTA Highlights of a Decade Series.

Published volumes are indicated below with their illustration. Other volumes forthcoming.

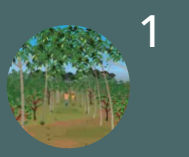

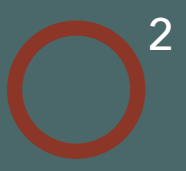

2

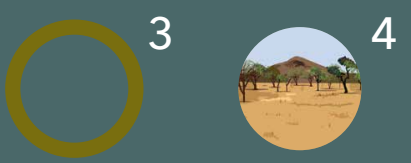

10

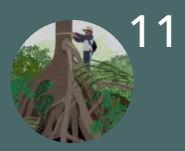

13

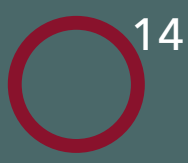

14

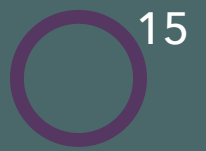

15

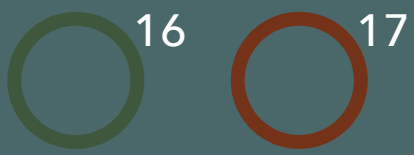

17

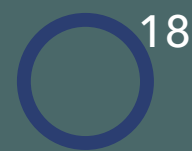

5

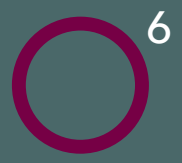

12

8 